\title{
Rozpoznawanie i leczenie chorych na nowotwory z dojrzałych komórek T i NK
}

\author{
Diagnosis and treatment of patients with mature T-cell \\ and NK-cell neoplasms
}

\author{
Krzysztof Warzocha, Bartosz Puła \\ Klinika Hematologii, Instytut Hematologii i Transfuzjologii, Warszawa
}

\begin{abstract}
Streszczenie
Nowotwory $z$ dojrzatych komórek $T i$ NK stanowia heterogenna grupe chorób wywodzacych sie z uktadu chtonnego. Do tej kategorii zalicza sie 10-15\% chtoniaków. Charakteryzuje je zróznicowany obraz kliniczny i patomorfologiczny, czeste lokalizacje pozaweztowe oraz niekorzystne rokowanie. Ich stosunkowo rzadkie wystepowanie, duza heterogenność oraz brak randomizowanych badań klinicznych utrudniaja opracowanie ujednoliconych standarów terapeutycznych. Niemniej chemioterapia oraz przeszczepianie krwiotwórczych komórek macierzystych zdaja sie być skuteczna metoda w leczeniu pierwszej linii oraz przypadków opornych i nawrotowych. W niniejszym artykule omówiono wytyczne diagnostyki i leczenia tej zróżnicowanej grupy nowotworów.
\end{abstract}

Słowa kluczowe: nowotwory z dojrzałych limfocytów T i NK, chemioterapia, przeszczepianie krwiotwórczych komórek macierzystych, rokowanie, diagnostyka

Hematologia 2017; 8, 3: 177-196

\begin{abstract}
Mature T-cell and NK-cell neoplasms comprise a heterogenous group of diseases of lymphoid origin. Approximately 10-15\% of the diagnosed lymphomas make up to this category. These neoplasms are characterized by differentiated clinical and pathomorphological traits, frequent extranodal manifestations and poor outcome. Given their relatively rare occurrence, high heterogeneity and lack of randomized clinical trials, work out of unified recommendations is difficult. Nevertheless, chemotherapy and hematopoietic stem cell transplantation seem to be effective in up-front and relapsed and refractory setting. In this publication we discuss the guidelines of diagnosis and treatment of this heterogenous malignancy group.
\end{abstract}

Key words: mature T-cell and NK-cell neoplasms, chemotherapy, hematopoietic stem cell transplantation, prognosis, diagnostics

Hematologia 2017; 8, 3: 177-196

\section{Wprowadzenie}

Nowotwory $z$ dojrzałych komórek T i NK ( $m a$ ture T-cell and NK-cell neoplasms) charakteryzują zróżnicowany obraz kliniczny i patomorfologiczny oraz częste lokalizacje pozawęzłowe. Stopień zróżnicowania komórkowego chłoniaków T pozwala na rozróżnienie postaci prekursorowych i wywodzących się $z$ dojrzałych komórek T i NK. Chłoniaki $z$ dojrzałych komórek T są klonalnymi nowotworami

Adres do korespondencji: Krzysztof Warzocha, Klinika Hematologii, Instytut Hematologii i Transfuzjologii, ul. Indiry Gandhi 14, 02-776 Warszawa, tel. 223496 334, faks 223496 335, e-mail: warzocha@ihit.waw.pl 
wywodzącymi się z pograsiczych limfocytów T. Nowotwory $z$ dojrzałych komórek NK pochodzą $z$ limfoidalnych prekursorów różnicujących się w kierunku komórek naturalnej cytotoksyczności (NK, natural killers) [1,2]. Różnorodność cech morfologicznych, genotypowych, biologicznych i klinicznych stała się podstawą do ich podziału na jednostki histokliniczne (klasyfikacja Światowej Organizacji Zdrowia [WHO, World Health Organization]) [3, 4].

W przeciwieństwie do B-komórkowych chłoniaków nie-Hodgkina (B-NHL, B-cell non-Hodgkin lymphoma) nowotwory $\mathrm{z}$ dojrzałych komórek $\mathrm{T}$ i NK nie doczekały się wieloośrodkowych badań klinicznych i wciąż brakuje jednoznacznych schematów postępowania leczniczego. W przypadku wielu $\mathrm{z}$ nich, w tym przede wszystkim chłoniaków skórnych, stosuje się ponadto inne klasyfikacje stopnia zaawansowania choroby, a także inne podejście terapeutyczne, ukierunkowane przede wszystkim na zmiany miejscowe [5].

Zależnie od obrazu klinicznego i do celów praktycznych nowotwory $z$ dojrzałych komórek $\mathrm{T}$ i NK można podzielić na nowotwory $[4,5]$ :

1) o pierwotnej lokalizacji $\mathrm{w}$ węzłach chłonnych i/lub innych narządach (T/NK-NHL), które szczegółowo omówiono w niniejszym artykule; 2) przebiegające $z$ obrazem białaczkowym, czyli pierwotnym zajęciem szpiku kostnego i krwi obwodowej - należą do nich białaczka prolimfocytowa T-komórkowa, białaczka $z$ dużych ziarnistych limfocytów T, przewlekła choroba limfoproliferacyjna $z$ komórek NK i agresywna białaczka $z$ komórek NK;

3) o pierwotnej lokalizacji skórnej, w tym: ziarniniak grzybiasty, zespół Sezary'ego, chłoniak $z$ komórek $T$ tkanki podskórnej typu zapalenia tkanki podskórnej, pierwotny skórny chłoniak anaplastyczny $\mathrm{z}$ dużych komórek, lymphomatoid papulosis, pierwotny skórny chłoniak $\mathrm{z}$ komórek T $\gamma / \delta$-dodatni, pierwotny agresywny skórny chłoniak epidermotropowy $z$ cytotoksycznych komórek T CD8+, pierwotny skórny chłoniak z małych/średnich komórek T CD4+.

\section{Epidemiologia}

W Europie zachorowania na nowotwory z dojrzałych komórek T i NK występują z częstością 1,5-2 przypadków/100 tys./rok. Mediana wieku zachorowania wynosi około 60 lat. Wśród wszystkich chorób nowotworowych układu chłonnego ich częstość występowania nie przekracza $10 \%$ i bardzo różni się w poszczególnych regionach świata [3]. W Europie i Ameryce
Północnej 2/3 zachorowań w tej grupie stanowią: chłoniaki $z$ obwodowych komórek T, bliżej nieokreślone (PTCL, NOS, peripheral T-cell lymphoma, not otherwise specified), chłoniak $z$ dużych komórek anaplastyczny (ALCL, anaplastic large cell lymphoma), chłoniak z komórek $\mathrm{T}$ angioimmunoblastyczny (AITL, angioimmunoblastic T-cell lymphoma). W Azji zdecydowanie częściej występują pozawęzłowy chłoniak $z$ komórek NK/T typu nosowego (ENKTCL, extranodal NK/T-cell lymphoma, nasal type) $\mathrm{i}$ inne nowotwory $\mathrm{z}$ komórek NK oraz białaczka/ /chłoniak z komórek T dorosłych (ATLL, adult T-cell leukemia/lymphoma) [3, 6-8].

\section{Patogeneza}

Zaburzenia mechanizmów kontrolujących proces dojrzewania prawidłowych limfocytów T i komórek NK mogą prowadzić do zapoczątkowania transformacji nowotworowej. Proces ten jest wieloetapowy, a jego rozpoczęcie może być zainicjowane działaniem różnych czynników. Należą do nich czynniki zewnętrzne, w tym wirusy, bakterie i substancje chemiczne, a także czynniki endogenne, w tym pierwotne i wtórne niedobory immunologiczne oraz przewlekła stymulacja układu immunologicznego własnymi antygenami w przebiegu chorób autoimmunizacyjnych. Wiele faktów przemawia również za istotną rolą rodzinnych predyspozycji genetycznych sprzyjających występowaniu chorób nowotworowych układu chłonnego.

Niezależnie od etiologii mechanizmy patogenetyczne prowadzące do transformacji nowotworowej prawidłowych limfocytów są podobne i polegają na wystąpieniu niestabilności genetycznej, $z$ następczym zaburzeniem regulacji stopnia ekspresji onkogenów i/lub utratą funkcji nowotworowych genów supresorowych. Aberracje chromosomowe zwykle nie mają charakteru przypadkowego i dotyczą obszarów cechujących się aktywną rearanżacją materiału genetycznego zachodzącą $\mathrm{w}$ warunkach fizjologicznych. Dla limfocytów T i ich prekursorów obszarami tymi są genowe loci regulatorowych części genów kodujących podjednostki receptora komórek T (TCR, T-cell receptor), w tym łańcuchy alfa i delta na chromosomie 14 . oraz beta i gamma na chromosomie $7[7,9]$.

\section{Diagnostyka}

\section{Objawy podmiotowe i przedmiotowe}

Większość chorych zgłasza się do lekarza z powodu powiększenia węzłów chłonnych i/ 
lub obecności guza w obszarze pozawęzłowym, a także $z$ powodu obecności objawów ogólnych choroby pod postacią stanów gorączkowych, potów nocnych i chudnięcia. Powiększone węzły chłonne są zwykle niebolesne, skóra nad nimi pozostaje niezmieniona, rozmiarami przekraczają średnicę $2 \mathrm{~cm}$ i wykazują tendencję do zrastania się w pakiety. Pozostałe objawy kliniczne mogą zależeć od zajęcia procesem chorobowym innych niż obwodowe węzły chłonne narządów limfatycznych i pozalimfatycznych.

W porównaniu $z$ B-NHL nowotwory $z$ grupy $\mathrm{T} /$ /NK-NHL zazwyczaj cechuje bardziej agresywny przebieg kliniczny, wyższy stopień zaawansowania klinicznego (CS, clinical stage) $\mathrm{w}$ momencie rozpoznania, częstsze lokalizacje pozawęzłowe i towarzyszące zespoły paranowotworowe oraz zespoły chorobowe, w tym zespoły eozynofilowe, hemofagocytowe i/lub autoimmunizacyjne [6, 10-12]. W konsekwencji chorzy są zwykle w gorszym stanie ogólnym, częściej występują u nich objawy ogólne choroby i wyjściowo są obarczeni większą liczbą obciążających czynników rokowniczych według Międzynarodowego Indeksu Prognostycznego (IPI, International Prognostic Index) [13].

\section{Badania laboratoryjne i obrazowe}

U każdego chorego $z$ podejrzeniem T/NK-NHL należy przeprowadzić dokładne badania podmiotowe i przedmiotowe, a następnie laboratoryjne i obrazowe w celu ustalenia optymalnego miejsca do przeprowadzenia biopsji diagnostycznej, zaawansowania klinicznego choroby i czynników rokowniczych.

Chirurgiczne wycięcie lub biopsja wycinająca (surgical excisional/incisional biopsy) jest zalecaną metodą pozyskania materiału diagnostycznego. W przypadku braku takiej możliwości zaleca się biopsję gruboigłową (core needle biopsy), choć uzyskiwany tą drogą materiał diagnostyczny jest zwykle niewystarczający. Biopsja cienkoigłowa (fine needle aspiration) jest przeciwwskazana.

$\mathrm{W}$ celu oceny materiału diagnostycznego zaleca się przeprowadzenie badania patologicznego przez doświadczonego hematopatologa, $z$ wykorzystaniem pozostałych parametrów kliniczno-laboratoryjnych w ramach pracy zespołu wielodyscyplinarnego (MDT, multidisciplinary team). W tym celu u wszystkich chorych należy przeprowadzić badania: morfologii krwi obwodowej, aktywności dehydrogenazy mleczanowej (LDH, lactate dehydrogenase), biochemicznych parametrów wydolności wątroby i nerek, wirusologiczne (na obecność: ludzkiego wirusa nabytego niedoboru odporności
[HIV, human immunodeficiency virus], wirusa wątroby typu B [HBV, hepatitis B virus], wirusa wątroby typu $\mathrm{C}[\mathrm{HCV}$, hepatitis $C$ virus], wirusa Epstein-Barr [EBV, Epstein-Barr virus]). Frakcja wyrzutowa lewej komory powinna być oceniona metodą echokardiografii lub angiografii radioizotopowej (MUGA, multigated acquisition scan) $\mathrm{u}$ wszystkich chorych powyżej 65. roku życia lub $z$ kardiologiczną przeszłością chorobową. Ponadto u kobiet w okresie rozrodczym należy rozważyć działania mające na celu zachowanie płodności, a u mężczyzn zamrożenie nasienia.

\section{Patomorfologia i biologia molekularna}

Diagnostyka oraz różnicowanie T/NK-NHL powinny się odbywać $\mathrm{w}$ ramach MDT, $z$ udziałem doświadczonego hematopatologa. W przebiegu T/ /NK-NHL ocenę klonalności komórek chłoniakowych przeprowadza się na podstawie ich morfologii cytologicznej, immunofenotypu oraz rearanżacji genów $(\alpha \beta v \cdot \gamma \delta)$ TCR [9]. Mają one nie tylko znaczenie diagnostyczne i rokownicze, ale także dla wyboru określonych metod leczenia (tab. 1) [14]. Markery, takie jak TIA-1, granzym B i perforyny, są charakterystyczne dla komórek cytotoksycznych, które mogą wskazywać na bardziej agresywny przebieg PTCL, NOS [15]. Obecność trzech spośród następujących markerów: CD10, BCL6, CXCL13, PD-1, SAP, ICOS czy CCR5, sugeruje pochodzenie komórek chłoniakowych $z$ grudkowych komórek T pomocniczych (FTH, follicular T-helper) $[9,16$, 17]. Stanowią one wraz $z$ hiperplazją grudkowych komórek dendrytycznych (FDC, follicular dendritic cells), oligoklonalnymi limfocytami B EBV(+) i zatartą strukturą węzła chłonnego - przez rozrost naczyń oraz liczne plazmocyty, neutrofile, eozynofile i komórki nabłonkowe w miejscu zanikowych ośrodków rozmnażania - podstawę rozpoznania AITL [7]. W preparatach histopatologicznych ENKTCL nacieki chłoniakowe są zlokalizowane wokól proliferujących naczyń, często z obecnością rozległej martwicy powstałej wskutek zamykania światła drobnych naczyń przez komórki nowotworowe, zwykle $\operatorname{EBV}(+)$. Komórki chłoniakowe charakteryzuje ekspresja antygenów T-komórkowych, w tym CD2 +, CD5+/-, CD7+/i często $\mathrm{CD} 4+\mathrm{i} \mathrm{CD} 8+$. Zwykle występuje wewnątrzcytoplazmatyczna ekspresja CD3 (łańcuch $\varepsilon$ ), $\mathrm{w}$ przeciwieństwie do innych PTCL, które wykazują powierzchniową ekspresję CD3 [3]. Obecność antygenu CD56 jest pomocna w różnicowaniu między postaciami chłoniaka $\mathrm{z}$ komórek $\mathrm{T}$ związanego $z$ enteropatią (EATL, enteropathy-associated T-cell lymphoma) typu 1 (CD8+/CD56-) oraz typu 2 
Tabela 1. Podtypy dojrzałych nowotworów z komórek T oraz NK (naturalnej cytotoksyczności) z uwzględnieniem immunofenotypu oraz wyjściowej komórki pochodzenia (zmodyfikowane za [14])

Table 1. Subtypes of mature T-cell and NK(natural killers)-cell neoplasms including their immunofenotype and cell of origin (modified from [14])

\begin{tabular}{|c|c|c|c|c|}
\hline Lokalizacja & Podtyp & Immunofenotyp & TCR & Komórki pochodzenia \\
\hline \multirow[t]{4}{*}{ Węzłowa } & PTCL, NOS & $\begin{array}{l}\text { CD4 > CD8; częsta } \\
\text { utrata CD5 oraz CD7; } \\
\text { CD30+/-; CD56+/-; } \\
\text { częściowo cechy FTH; } \\
\text { ziarnistości } \\
\text { cytotoksyczne+/- }\end{array}$ & $\alpha \beta$, rzadko $\gamma \delta$ & $\begin{array}{l}\text { Zróżnicowane, przeważnie komórki T } \\
\text { pomocnicze }\end{array}$ \\
\hline & AITL & $\begin{array}{l}\text { CD4+; CD10+/-; } \\
\text { BCL+/-; CXCL13+; } \\
\text { PD1+, ICOS+/-; SAP+/-; } \\
\text { CCR5+/-; hiperplazja } \\
\text { FDC; EBV+ blasty } \\
\text { z komórek B }\end{array}$ & $\alpha \beta$ & FTH \\
\hline & ALCL ALK+ & $\begin{array}{l}\text { ALK+; CD30+; EMA+; } \\
\text { CD25+; ziarnistości } \\
\text { cytotoksyczne+; CD4+/-; } \\
\text { CD3+/- }\end{array}$ & $\alpha \beta$ & Komórki T cytotoksyczne \\
\hline & ALCL ALK- & $\begin{array}{l}\text { ALK-; CD30+; EMA+; } \\
\text { CD25+; ziarnistości } \\
\text { cytotoksyczne+; CD4+/-; } \\
\text { CD3+/- }\end{array}$ & $\alpha \beta$ & Komórki T cytotoksyczne \\
\hline \multirow[t]{4}{*}{ Pozawęzłowa } & EATL, typ 1 & $\begin{array}{l}\text { CD8(+)/-; CD56-; } \\
\text { HLA-DQ2/-DQ8 }\end{array}$ & $\alpha \beta$ & $\begin{array}{l}\text { Śródnabłonkowe komórki T }(\alpha \beta) \text {, } \\
\text { wywiad enteropatii }\end{array}$ \\
\hline & EATL, typ 2 & $\begin{array}{l}\text { CD8+; CD56+; } \\
\text { HLA-DQ2/-DQ8 }\end{array}$ & $\gamma \delta$ lub $\alpha \beta$ & $\begin{array}{l}\text { Śródnabłonkowe komórki T lub NK } \\
(\alpha \beta) \text {, bez wywiadu enteropatii }\end{array}$ \\
\hline & ENKTCL & $\begin{array}{l}\text { CD2+; CD56+; po- } \\
\text { wierzchniowe CD3-; } \\
\text { cytoplazmatyczny } \\
\text { CD3 }+ \text { + granzym B+; } \\
\text { TIA-1+; perforyna+; } \\
\text { EBV+; LMP1 }\end{array}$ & $\begin{array}{l}\text { TCR w układzie } \\
\text { zarodkowym, } \\
\text { rzadko } \alpha \beta \text { lub } \gamma \delta\end{array}$ & Komórki NK, rzadko T cytotoksyczne \\
\hline & HSTCL & $\begin{array}{l}\text { CD3+, CD56+/-, CD4-, } \\
\text { CD8+/-, CD5-, TIA-1+, } \\
\text { granzym M+, granzym } \\
\text { B-, perforyna- }\end{array}$ & $\gamma \delta$, rzadko $\alpha \beta$ & $\begin{array}{l}\text { Komórki T cytotoksyczne wrodzonego } \\
\text { układu immunologicznego }\end{array}$ \\
\hline
\end{tabular}

TCR (T-cell receptor) - receptor komórek T; PTCL, NOS (peripheral T-cell lymphoma, not otherwise specified) - chłoniak z obwodowych komórek T, bliżej nieokreślony; AITL (angioimmunoblastic T-cell lymphoma) - chłoniak z komórek T angioimmunoblastyczny; FDC (follicular dendritic cells) - grudkowe komórki dendrytyczne; FTH (follicular T-helper) - grudkowe komórki T pomocnicze; ALCL (anaplastic large cell lymphoma) - chłoniak z dużych komórek anaplastyczny; EATL (enteropathy-associated T-cell lymphoma) - chłoniak z komórek T związany z enteropatią; ENKTCL (extranodal NK/T-cell lymphoma, nasal type) - pozawęzłowy chłoniak z komórek NK/T typu nosowego; HSTCL (hepatosplenic T-cell lymphoma) - chłoniak z komórek T wątrobowo-śledzionowy

$(\mathrm{CD} 8-/ \mathrm{CD} 56+)$, który częściej ma fenotyp $\gamma \delta+$ i nie jest związany $z$ występowaniem celiakii [3]. Antygen CD30 odgrywa zasadniczą rolę w rozpoznawaniu ALCL; jego postać układowa jest zwykle PAX5(-), często EMA(+) i w $1 / 3$ przypadków CD45(-). Dalsze różnicowanie polega na kategoryzacji przypadków ALK(+) versus ALK(-), zależnie od obecności lub braku klasycznej translokacji t $(2 ; 5)$ lub jej wariantów [3, 9]. Obecność antygenów CD20 i PAX5 pozwala na wykrycie w nacieku chłoniakowym komórek B, a tym samym różnicowanie postaci ALCL ALK $(-)$ z podtypem anaplastycznym PAX5(+) klasycznego chłoniaka
Hodgkina (cHL, classical Hodgkin lymphoma). Ocena obecności genomu EBV (EBER, Epstein- Barr encoding region) jest ważna dla potwierdzenia rozpoznania niektórych postaci T/NK-NHL, w tym zwłaszcza ENKTCL.

\section{Kryteria rozpoznania i różnicowanie}

Obecnie obowiązującą klasyfikacją T/NK-NHL jest podział zaproponowany przez WHO w 2016 roku, w którym za podstawę diagnostyczną przyjęto kryteria histopatologiczne, immunohistochemiczne, metody cytogenetyczne, molekularne i obraz kliniczny choroby [4]. 


\section{Określenie stopnia zaawansowania}

Ocenę stopnia zaawansowania należy przeprowadzić na podstawie zmodyfikowanej w Lugano klasyfikacji z Ann Arbor [18]. Stopnie zaawansowania I i II określa się lącznie jako zaawansowanie ograniczone, a III i IV - jako zaawansowanie rozległe. Zmiany masywne oznaczają występowanie guza o wymiarach co najmniej $7,5 \mathrm{~cm}$. Ze względu na większą czułość badania i lepszą ocenę skuteczności leczenia, a także zalecenia międzynarodowej grupy roboczej z Lugano [18] u wszystkich chorych zaleca się przeprowadzenie trepanobiopsji szpiku kostnego i badania metodą pozytonowej tomografii emisyjnej/tomografii komputerowej (PET, positron emission tomography/CT, computed tomography), zwłaszcza w przypadku występowania choroby pozawęzłowej [19-29]. W przypadku braku dostępności PET/CT należy wykonać badanie CT ze wzmocnieniem kontrastowym okolic szyi, klatki piersiowej, jamy brzusznej i miednicy.

Badanie rezonansu magnetycznego (MRI, magnetic resonance imaging) $\mathrm{w}$ połączeniu $\mathrm{z} \mathrm{CT}$ mózgowia, oczodołów i zatok zaleca się u chorych $z$ podejrzeniem zajęcia ośrodkowego układu nerwowego (OUN) lub okolic twarzoczaszki. Diagnostyczna punkcja lędźwiowa, $z$ analizą płynu mózgowo-rdzeniowego (CSF, cerebrospinal fluid) za pomocą badania cytologicznego i cytometrii przepływowej, jest zalecana w przypadku podejrzenia zajęcia OUN lub wysokiego ryzyka wystąpienia takiej lokalizacji; jednoczasowo należy dokanałowo podać metotreksat (MTX, methotrexate).

\section{Czynniki predykcyjne i prognostyczne}

Większość chorych na T/NK-NHL zalicza się do grup prognostycznych wysokiego ryzyka według IPI (> 2 obciążające czynniki ryzyka), co ogranicza jego praktyczne zastosowanie [30-32]. W odniesieniu do niektórych podtypów, w tym pierwotnych chłoniaków skóry, EATL czy ENKTCL, klasyfikacja IPI może w ogóle być nieprzydatna. Dlatego wciąż trwają poszukiwania bardziej specyficznych indeksów rokowniczych dla określonych podtypów T/ /NK-NHL [33]. Przykładem jest PIT (Prognostic Index for PTCL) [34, 35], oceniany na podstawie stanu ogólnego według Eastern Cooperative Oncology Group (ECOG), wieku aktywności LDH i zajęcia szpiku kostnego. Za pomocą wymienionych wyżej parametrów definiuje się 4 grupy ryzyka ( $0,1,2$ lub $>3$ czynników obciążających) różniące się istotnie między sobą odsetkami 5-letniego OS, odpowiednio $62 \%, 53 \%, 33 \%$ i $18 \%$ [34]. Innym przykładem jest indeks rokowniczy dla AITL uwzględniający wiek ( $<$ lub $\geq 60$ lat), stan ogólny według ECOG (< lub $\geq 2$ ), liczbę lokalizacji pozawęzłowych ( $\leq$ lub $>1)$, obecność lub brak objawów ogólnych (gorączka, utrata masy ciała, nocne poty), liczbę płytek kwi ( $>$ lub $\leq 150 \mathrm{G} / \mathrm{l})$; pozwala on na wyróżnienie grup chorych o niskim (5-letni OS 44\%) i wysokim ryzyku (5-letni OS 24\%) [36].

Do innych czynników o znaczeniu rokowniczym dla NK/T-NHL zalicza się także indeks proliferacyjny Ki-67, wyjściowe surowicze stężenia białka całkowitego, ekspresję molekuł cytotoksycznych (T1A-1, granzym B) i antygenu CD30 oraz zaburzenia cytogenetyczne. Do tych ostatnich należą aberracje o korzystnym [del(5q), del(10q), del(12q)] oraz o złym rokowaniu (mutacje TP53). Do niekorzystnych czynników rokowniczych należą również płeć męska i wysokie miano kopii DNA EBV w przypadku ENKTCL [37-39].

\section{Leczenie}

Zasadniczym celem leczenia u chorych na $\mathrm{T} /$ /NK-NHL, kwalifikujących się do leczenia radykalnego, jest uzyskanie całkowitej remisji (CR) i wyleczenia, a u pozostałych - poprawa jakości życia oraz wydłużenie przeżycia wolnego od progresji (PFS, progression-free survival) i przeżycia całkowitego (OS, overall survival). Strategie terapeutyczne są głównie uwarunkowane wyjściowym zaawansowaniem choroby i czynnikami rokowniczymi, wiekiem i stanem ogólnym chorego oraz chorobami towarzyszącymi i wyborem pacjenta. W każdym przypadku należy rozważyć kwalifikowanie chorych do odpowiednich badań klinicznych.

\section{Leczenie pierwszego rzutu}

W klinicznych bazach danych, obejmujących około 1500 chorych na T/NK-NHL w ITCP (International T-cell Project) i BCCA (British Columbia Cancer Agency), ponad 85\% protokołów leczenia początkowego opierało się na schematach podobnych do CHOP (cyklofosfamid, doksorubicyna, winkrystyna, prednizolon) [8, 31, 32, 36, 40, 41]. Bardziej intensywne protokoły, w tym EPOCH (etopozyd, prednizon, winkrystyna, cyklofosfamid, doksorubicyna) czy hyper-CVAD (cyklofosfamid, winkrystyna, adriamycyna, deksametazon), nie tylko nie okazały się bardziej skuteczne, ale były bardziej toksyczne w porównaniu z CHOP. Podobnie w innym badaniu III fazy Groupe Ouest-Est d'Étude des Leucémies Aigües et Autres Maladies $d u$ Sang (GOELAMS), w którym porównywano CHOP z naprzemiennymi cyklami ICE (etopozyd, ifosfamid, cisplatyna)/ABVD (adriamycyna, bleomycyna, winblastyna, dakarbazyna), nie uzyskano 
znaczących różnic w obu grupach, które oscylowały wokół $70 \%$ całkowitego odsetka odpowiedzi (ORR, overall response rate) i 35\% CR [42].

Próbą zakończoną zwiększeniem skuteczności CHOP było dołączenie etopozydu (CHOEP). W 7 różnych badaniach II i III fazy, przeprowadzonych przez DSHNHL (Deutsche Studiengruppe Hochmaligne Non-Hodgkin Lymphome) u tącznie 320 chorych na T/NK-NHL (78 na ALCL ALK+, 113 na ALCL ALK-, 70 na PTCL, NOS, 28 na AITL oraz 31 innych podtypów T/NK-NHL), wykazano przewage schematu CHOEP u chorych poniżej 60. roku życia i z prawidłowymi wartościami LDH w zakresie PFS $(75,4 \% v$. 51\%), ale bez wpływu na OS [43-45]. Największą korzyść $z$ dołączenia etopozydu obserwowano w grupie ALCL ALK(+) i choć podobny trend obserwowano w odniesieniu do innych podtypów histopatologicznych, to znacząca nadreprezentacja tego rozpoznania wśród wszystkich leczonych chorych mogła wpłynąć na globalne wyniki analiz [45]. W badaniach wykazano także, że dołączenie etopozydu wiązało się $z$ istotnym nasileniem toksyczności $\mathrm{w}$ grupie chorych w starszym wieku (> 60. rż.) [43-45].

Kolejną próbą poprawy wyników leczenia, po początkowej odpowiedzi uzyskanej za pomocą 6 cykli CHOEP podawanych co 14 dni (CHOEP-14), była konsolidacja wysokodawkowaną chemioterapią (CTH, chemotherapy) według schematu BEAM (karmustyna, etopozyd, arabinozyd cytozyny, melfalan lub cyklofosfamid) wspomaganą przeszczepieniem autologicznych krwiotwórczych komórek macierzystych (auto-HSCT, autologous hematopoietic stem cell transplantation). W badaniu II fazy po zastosowaniu takiego protokołu (etopozydu nie stosowano u chorych $>60$. rż.) uzyskano $82 \%$ ORR i $51 \%$ CR [46]. W innych badaniach II fazy, służących ocenie skuteczności i toksyczności protokołu CHOP i konsolidacji za pomocą auto-HSCT, ORR/CR wynosił odpowiednio 79\%/39\% oraz $66 \% / 56 \%$ [38, 47].

Wyniki przedstawionych badań nad rolą auto-HSCT w konsolidacji początkowej odpowiedzi skłaniają do wykorzystywania procedury transplantacyjnej w pierwszej linii leczenia, choć brakuje w tym zakresie badań randomizowanych [48-51]. W badaniu d'Amore i wsp. [38], przeprowadzonym u 160 chorych (39\% PTCL, NOS, 19\% ALCL ALK(-), 19\% AITL), u 71\% chorych przeprowadzono auto-HSCT. Odstetki 5-letniego PFS (44\%) i OS $(51 \%)$ zależały od podtypu chłoniaka (w badaniu nie uczestniczyli chorzy na ALCL ALK+) i wynosity odpowiednio: $61 \%$ i $70 \%$ (ALCL ALK-), $38 \%$ i $47 \%$ (PTCL, NOS), $49 \%$ i 52\% (AITL) [38].
Podobne wyniki uzyskano u 83 chorych na T/NK-NHL po zastosowaniu CHOP i konsolidacji auto-HSCT (66\% leczonych chorych) - 3-letni OS w całej badanej grupie wyniósł $48 \%$, w tym $71 \%$ $\mathrm{u}$ chorych poddanych auto-HSCT [47]. Analogiczne wyniki uzyskano w Memorial Sloan Kettering Cancer Center u 62 chorych (mediana wieku 58 lat) na PTCL, NOS, AITL lub ALCL ALK(-), po początkowym zastosowaniu schematów podobnych do CHOP i konsolidacji odpowiedzi u $63 \%$ chorych za pomocą auto-HSCT - 4-letnie PFS i OS wynosiły odpowiednio $40 \%$ i $53 \%$ [52]. Czynnikiem o największym znaczeniu predykcyjnym dobrej odpowiedzi w tym badaniu był negatywny wynik PET po 4 cyklach leczenia początkowego; odsetek 5-letniego PFS u tych chorych, z których $53 \%$ stanowili chorzy wysokiego ryzyka według IPI (> 2), wynosił 59\% [52].

Ograniczone możliwości udoskonalenia protokołów CTH pierwszej linii, w tym nieudokumentowana w badaniach prospektywnych rola auto-HSCT w konsolidacji, skłaniają badaczy do poszukiwania innych rozwiązań i nowych leków. Pralatreksat należy do nowej generacji antagonistów kwasu foliowego zaburzających syntezę DNA przez odwracalne zahamowanie reduktazy dihydrofolianowej [53]. W porównaniu z MTX działa silniej i bardziej wybiórczo na komórki nowotworowe. $\mathrm{W}$ badaniach klinicznych I i II fazy u wcześniej leczonych chorych na nawrotowe postaci PTCL, NOS, ALCL i AITL pralatreksat zastosowany w dawce $30 \mathrm{mg} /$ $/ \mathrm{m}^{2} /$ tydzień do czasu progresji choroby umożliwił uzyskanie $29-54 \%$ ORR, w tym długo trwających CR u chorych $z$ pierwotnie chemioopornymi chłoniakami [53, 54]. Ze względu na toksyczność pralatreksatu (zapalenie błon śluzowych u ok. $70 \%$, nudności u ok. $40 \%$ i małopłytkowość u ok. $40 \%$ pacjentów) jego jednoczasowe dołączenie do protokołów CTH nie wydaje się możliwe, ale trwa badanie III fazy wykorzystujące jego potencjał w konsolidacji początkowej odpowiedzi uzyskanej za pomocą CHOP (NCT01420679) [53, 54].

Inną obiecującą grupą leków są inhibitory deacetylaz histonowych (HDAC, histone deacetylase), $\mathrm{w}$ tym zwłaszcza romidepsyna, której zastosowanie w monoterapii w dawce $14 \mathrm{mg} / \mathrm{m}^{2}$ (w dniach $1 ., 8$. i 15. w cyklach co 28 dni do czasu progresji choroby) u chorych na nawrotowe PTCL, w tym PTCL, NOS, AITL i ALCL ALK(-), umożliwiło uzyskanie 25-38\% ORR, w tym 15-18\% CR [55, 56]. Wyniki tych badań były podstawą podjęcia prób skojarzenia romidepsyny z CHOP u wcześniej nieleczonych chorych, w tym w ramach randomizowanych badań klinicznych III fazy (NCT01796002) [57]. Innymi 


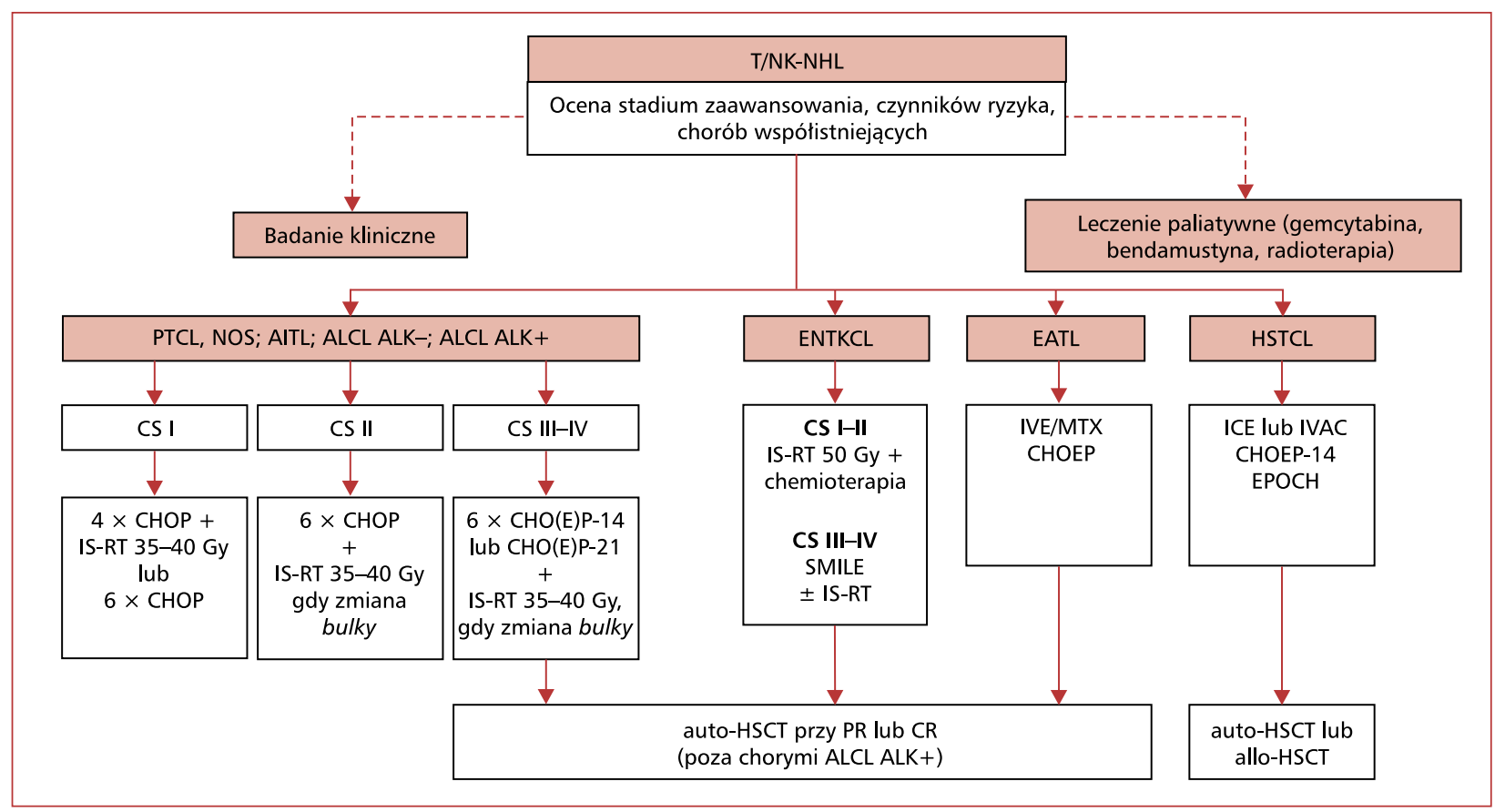

Rycina 1. Algorytm leczenia pierwszej linii u chorych na chłoniaki z dojrzałych komórek T i NK (naturalnej cytotoksyczności) o pierwotnej lokalizacji w węzłach chłonnych i/lub innych narządach (T/NK-NHL); PTCL, NOS — chłoniak z obwodowych komórek T, bliżej nieokreślony; AITL — chłoniak z komórek T angioimmunoblastyczny; ALCL — chłoniak z dużych komórek anaplastyczny; ENKTCL — pozawęzłowy chłoniak z komórek NK/T typu nosowego; EATL — chłoniak z komórek T związany z enteropatią; HSTL — chłoniak z komórek T wątrobowo-śledzionowy; CS — stadium zaawansowania; CHOP — cyklofosfamid, doksorubicyna, winkrystyna, prednizon; IS-RT — radioterapia zajętej okolicy; CHO(E)P - cyklofosfamid, doksorubicyna, winkrystyna, etopozyd, prednizon; SMILE — steroid (deksametazon), metotreksat, ifosfamid, L-asparaginaza, etopozyd; IVE/MTX — ifosfamid, etopozyd, wysokodawkowany metotreksat; ICE — etopozyd, ifosfamid, cisplatyna; IVAC — ifosfamid, cytarabina, etopozyd; PR — remisja częściowa; CR — całkowita remisja; auto-HSCT — przeszczepienie autologicznych krwiotwórczych komórek macierzystych; allo-HSCT — przeszczepienie allogenicznych krwiotwórczych komórek macierzystych

Figure 1. Upfront treatment algorithm of patients with mature T and NK (natural killers) cell lymphomas of primary nodal or extranodal localization (T/NK-NHL); PTCL, NOS - peripheral T-cell lymphoma, not otherwise specified; AITL — angioimmunoblastic T-cell lymphoma; ALCL — anaplastic large cell lymphoma; ENKTCL — extranodal NK/T-cell Iymphoma, nasal type; EATL — enteropathy-associated T-cell lymphoma; HSTL — hepatosplenic T-cell Iymphoma; CS — clinical stage; CHOP — cyclofosfamide, doxorubicine, vincristine, prednisone; IS-RT — involved-site radiotherapy; $\mathrm{CHO}(\mathrm{E}) \mathrm{P}$ - cyclofosfamide, doxorubicine, vincristine, etoposide, prednisone; SMILE — steroid (dexamethasone), methotrexate, ifosfamide, L-asparaginase, etoposide; IVE/MTX — ifosfamide, etoposide, high-dose methotrexate; ICE — etoposide, ifosfamide, cisplatine; IVAC — ifosfamide, cytarabine, etoposide; PR - partial remission; CR - complete remission; auto-HSCT — autologous hematopoietic stem cell transplantation; allo-HSCT — allogeneic hematopoietic stem cell transplantation

lekami z grupy inhibitorów HDAC testowanymi obecnie u chorych na PTCL są belinostat i panobinostat [58].

Lekiem, $z$ którym wiąże się największe nadzieje poprawy wyników leczenia chorych na $\mathrm{T} /$ /NK-NHL CD30+, jest brentuksymab wedotin (BV, brentuximab vedotin) - przeciwciało monoklonalne anty-CD30 skoniugowane $z$ cząsteczką cytotoksyczną (monometyloaurystatyna E) o działaniu antytubulinowym, która po związaniu kompleksu $z$ receptorem przedostaje się do wnętrza komór- ki docelowej, powodując zatrzymanie jej cyklu podziałowego i apoptozę. W badaniu II fazy u 58 chorych $\mathrm{z}$ nawrotową (62\% pierwotna chemiooporność) postacią ALCL (72\% ALCL ALK-) $\mathrm{BV}$ podawany $\mathrm{w}$ monoterapii $\mathrm{w}$ dawce $1,8 \mathrm{mg} /$ /kg mc. co 3 tygodnie (do 16 dawek) pozwolił na uzyskanie $86 \%$ ORR ( $57 \% \mathrm{CR}$ ), z medianą czasu trwania odpowiedzi wynoszącą 12,6 miesiąca [59]. Najczęstszymi objawami niepożądanymi były przemijająca neuropatia (41\%) i cytopenie (neutropenia i małopłytkowość) [59]. Skuteczność BV 
potwierdzono także u chorych na inne chłoniaki CD30+, w tym na nawrotowego HL, AITL (54\% ORR) i PTLC, NOS (33\% ORR) [60, 61]. Trwa randomizowane badanie kliniczne III fazy służące ocenie skuteczności i toksyczności skojarzenia BV z CHP (cyklofosfamid, doksorubicyna, winkrystyna) w porównaniu $z$ CHOP u wcześniej nieleczonych chorych na nowotwory $z$ dojrzałych komórek T CD30 + (ECHELON-2, NCT01777152). Chorzy niekwalifikujący się do leczenia radykalnego mogą być kwalifikowani do monoterapii gemcytabiną [62] lub bendamustyną [63].

Algorytm postępowania terapeutycznego $\mathrm{w}$ pierwszej linii przedstawiono na rycinie 1 . Podsumowując:

- u chorych na wczesną postać (CS I) bez zmiany masywnej $(<7,5 \mathrm{~cm})$ zaleca się zastosowanie 3-4 cykli CHOP z uzupełniającą radioterapią (IS-RT, involved-site radiotherapy) $\mathrm{w}$ dawce 35-40 Gy na okolice dobrej tolerancji radioterapii (pachwina, pacha, szyja). Alternatywą dla leczenia skojarzonego może być, w przypadku lokalizacji choroby w obszarach predestynowanych do wystąpienia wczesnej lub późnej toksyczności po radioterapii, wyłączna CTH 6 cyklami CHOP [64-66];

- u chorych na wczesną postać (CS II) bez zmiany masywnej $(<7,5 \mathrm{~cm})$ zaleca się zastosowanie 6 cykli CHOP;

- u chorych na wczesną postać (CS I-II) ze zmianą masywną $(\geq 7,5 \mathrm{~cm})$ zaleca się zastosowanie 6 cykli CHOP z uzupełniającą IS-RT, w dawce 35-40 Gy, na obszary bulky [66];

- w przypadku postaci zaawansowanej (CS III-IV) zaleca się zastosowanie 6-8 cykli CHOP co 21 dni (CHOP-21), których wariantami u chorych poniżej 65. roku życia mogą być protokoły CHOEP-21 lub CHOEP-14. W celu konsolidacji remisji można rozważyć zastosowanie, $z$ wyjątkiem chorych na ALCL ALK(+), wysokodawkowanej CTH wspomaganej auto-HSCT, zwłaszcza w ramach protokołów badań klinicznych;

- $u$ chorych obciążonych czynnikami ryzyka zajęcia OUN należy rozważyć profilaktykę [67].

\section{Choroba oporna lub nawrotowa}

W przypadku wystąpienia oporności lub nawrotu zaleca się przeprowadzenie biopsji potwierdzającej rozpoznanie wraz z oceną stopnia zaawansowania choroby. $Z$ wyjątkiem T/NK-NHL CD30+ nie ma jednoznacznych wytycznych postępowania $\mathrm{w}$ drugiej i kolejnych liniach leczenia. Wyjątkiem jest zastosowanie BV w przypadku nawrotu ukła- dowego ALCL, bez względu na status ALK [68]. $\mathrm{W}$ badaniu II fazy monoterapia BV $\mathrm{u}$ intensywnie przeleczonych chorych $z$ tym rozpoznaniem umożliwiła uzyskanie $86 \%$ odsetka ORR i $57 \%$ CR, $z$ medianą czasu twania odpowiedzi 12,6 miesiąca [59]. Takie postępowanie może być również skutecznym pomostowaniem do procedury przeszczepienia allogenicznych krwiotwórczych komórek macierzystych (allo-HSCT, allogeneic hematopoietic stem cell transplantation), także w nawrotach innych chłoniaków CD30+, w tym AITL i PTCL, NOS.

U pozostałych chorych, w dobrym stanie ogólnym i kwalifikujących się do intensywnego leczenia, zaleca się podanie CTH ratunkowej i auto-HSCT. Wybór schematu leczenia drugiej linii powinien zależeć od spodziewanego profilu toksyczności i możliwości skolekcjonowania krwotwórczych komórek macierzystych do przeszczepienia. Głównym celem leczenia ratunkowego jest zmniejszenie masy nowotworu i wykazanie chemiowrażliwości przed procedurą auto-HSCT [69]. Większość protokołów leczenia drugiej linii zawiera związki platyny i/lub ifosfamid [70], konsolidowanych w przypadku uzyskania odpowiedzi wysokodawkowaną CTH według schematu BEAM (BCNU, etopozyd, cytarabina, melfalan) i auto-HSCT. Ze względu na toksyczność późną radioterapii całego ciała (TBI, total body irradiation) preferuje się stosowanie wyłącznej CTH [71], z możliwością zastosowania miejscowej radioterapii uzupełniającej na zmiany rezydualne [66, 72, 73]. Choć uzyskanie CR nie jest koniecznym warunkiem do przeprowadzenia auto-HSCT, to wynik badania PET przed przeszczepieniem pozostaje istotnym czynnikiem predykcyjnym dalszego rokowania [74-76]. Najlepsze wyniki uzyskuje sie w przypadku uzyskania metabolicznej CR przed auto-HSCT [77, 78].

Roli konsolidującej radioterapii przed lub po auto-HSCT również nie określono. Niektóre wyniki badań wskazują na korzyść $z$ jej stosowania w przypadku rezydualnych zmian masywnych [72, 76], ale inne przeczą jej wykorzystaniu w tym wskazaniu klinicznym [79, 80]. Racjonalnym celem radioterapii wydają się natomiast zmiany rezydulane PET(+) po zakończeniu leczenia ratunkowego. W tym przypadku dawka powinna być zindywidualizowana, chociaż w przypadkach lokoregionalnej wznowy lub choroby opornej powinna być większa (do 55 Gy) niż w przypadku radioterapii zmian pierwotnych. Nie ma jednoznacznych dowodów przemawiających za tym, czy radioterapia powinna być przeprowadzona przed, czy po auto-HSCT.

Rokowanie u chorych, którzy nie odpowiedzieli na leczenie drugiej linii, jest złe, $z$ odsetkami 
1-3-letnich OS nieprzekraczającymi 10\% [81, 82]. W takim przypadku chorzy powinni być kwalifikowani do leczenia kolejnej linii, najlepiej w ramach badań klinicznych nad nowymi cząstkami. Nie ma badań, w których porównano by bezpośrednio skuteczność i toksyczność różnych schematów CTH w drugiej i kolejnych liniach leczenia, ale możliwość zastosowania allo-HSCT (3-letni PFS wynosi ok. $60 \%$ ) jest ważna dla wyboru rodzaju CTH ratunkowej. W przypadku możliwości przeprowadzenia transplantacji zaleca się wykorzystanie schematów wielolekowych, takich jak ICE (etopozyd, ifosfamid, cisplatyna) lub DHAP (deksametazon, arabinozyd cytozyny, cisplatyna), które wykazują duży potencjał cytoredukcyjny niezbędny do uzyskania remisji, ale ze względu na toksyczność liczba cykli, które można zastosować, zwykle nie przekracza $3-4$. Rokowanie u chorych $z$ nawrotem po auto-HSCT jest złe [83]. Tylko nieliczni pacjenci wykazują odpowiedź na leczenie ratunkowe kolejnej linii, a tym samym są potencjalnymi kandydatami do procedury allo-HSCT [84-93]. Czas do nawrotu choroby po auto-HSCT i chemiowrażliwość na leczenie ratunkowe kolejnej linii to najważniejsze czynniki predykcyjne powodzenia leczenia. Chorzy, którzy nie uzyskali co najmniej PR, nie powinni być kwalifikowani do allo-HSCT.

Wybór przygotowania mieloablacyjnego $\mathrm{w}$ porównaniu $\mathrm{z}$ kondycjonowaniem o zredukowanej intensywności (RIC, reduced-intensity conditioning) przed allo-HSCT jest trudny, ponieważ $\mathrm{w}$ dostępnych badaniach w tym zakresie stosowano zróżnicowane kryteria włączenia [88, 90-92, 94, 95]. Co do zasady postępowanie mieloablacyjne ogranicza się do chorych młodszych (< 40 rż.), u których nie przeprowadzano wcześniej auto-HSCT, a $\mathrm{u}$ pozostałych chorych preferowaną strategią postępowania jest RIC-allo-HSCT.

W przypadku braku możliwości przeprowadzenia allo-HSCT racjonalnym podejściem terapeutycznym będzie zastosowanie mniej toksycznych protokołów, w tym opartych na uznanych cytostatykach (gemcytabina, bendamustyna) [62, 63, 96] i lekach immunomodulujących (lenalidomid) [97] lub nowych cząsteczkach (BV, pralatreksat, romidepsyna, belinostat) [54-56, 59-61, 98], które można podawać przez dłuższy czas. Ich wybór zależy przede wszystkim od dostępności, gdyż odsetki uzyskiwanych odpowiedzi są podobne i mieszczą się w przedziale $25-86 \%$ ORR (10-57\% CR). Gemcytabina w monoterapii $\left(1200 \mathrm{mg} / \mathrm{m}^{2}\right.$ $\mathrm{w}$ dniach 1., 8. i 15.) u chorych na nawrotowe PTCL pozwala na uzyskanie około $50 \%$ ORR, w tym $23 \%$ CR [62]. Skojarzenie jej z innymi cytostatykami, w tym oksaliplatyną i deksametazonem lub etopozydem, cisplatyną i metyloprednizolonem, choć dobrze tolerowane (także u chorych w starszym wieku), nie zwiększyło odsetków odpowiedzi [99, 100]. Podobnie bendamustyna zastosowana w monoterapii $\left(120 \mathrm{mg} / \mathrm{m}^{2} \mathrm{w}\right.$ dniach 1 . i 2. co 3 tygodnie, do 6 cykli) umożliwia uzyskanie około $50 \%$ ORR (28\% CR) u chorych $z$ nawrotową postacią PTCL, NOS i AITL, ale czas trwania odpowiedzi jest zwykle krótki (ok. 3,5 miesiąca) [63]. Podobnie trwające krótko odpowiedzi (30\% ORR) w kolejnej linii leczenia uzyskano za pomocą lenalidomidu w monoterapii $(25 \mathrm{mg} / \mathrm{d}$. w dniach od 1 . do 21 ., w cyklach co 28 dni) [97].

Na uwagę zasługują także inne metody leczenia, $\mathrm{w}$ tym polegające na zastosowaniu inhibitora kinazy ALK (krizotynib) u chorych na ALCL ALK(+) [101, 102], inhibitorów HDAC (romidepsyna, belinostat) u chorych na AITL czy inhibitora szlaku kinazy Aurora A (alisertib) [103]. Badanie kliniczne III fazy, w którym porównywano w tych wskazaniach klinicznych alisertib z gemcytabiną, pralatreksatem lub romidepsyną, jest realizowane (NCT01482962). $\mathrm{U}$ pozostałych chorych, niekwalifikujących się do CTH lub/i badań klinicznych, należy wdrożyć postępowanie objawowe (BSC, best supportive care).

Algorytm leczenia chorych w drugiej i kolejnej linii przedstawiono na rycinie 2. Podsumowując:

- w przypadku podejrzenia nawrotu T/NK-NHL zaleca się wykonanie biopsji potwierdzającej;

- chorych kwalifikujących się do auto-HSCT należy poddać leczeniu ratunkowemu opartemu na CTH niewykazującej krzyżowej oporności wobec wcześniej stosowanych leków, a po uzyskaniu CR - auto-HSCT;

- chorych uzyskujących PR po leczeniu ratunkowym należy poddać CTH kolejnej linii, a w przypadku uzyskania CR — konsolidacji za pomocą auto-HSCT; auto-HSCT należy także rozważyć u chorych uzyskujących PR;

- przed auto-HSCT zaleca się przeprowadzenie badania PET;

- w przypadku lokoregionalnych nawrotów choroby, zwłaszcza będących zmianami PET $(+)$ po zakończeniu leczenia ratunkowego, należy rozważyć przeprowadzenie radioterapii okołotransplantacyjnej;

- niektórzy chorzy z nawrotem choroby po auto-HSCT mogą być kandydatami do leczenia ratunkowego kolejnej linii i procedury allo-HSCT;

- przeciwciało anty-CD30 (BV) jest postępowaniem $z$ wyboru w nawrotowych i opornych postaciach ALCL. 


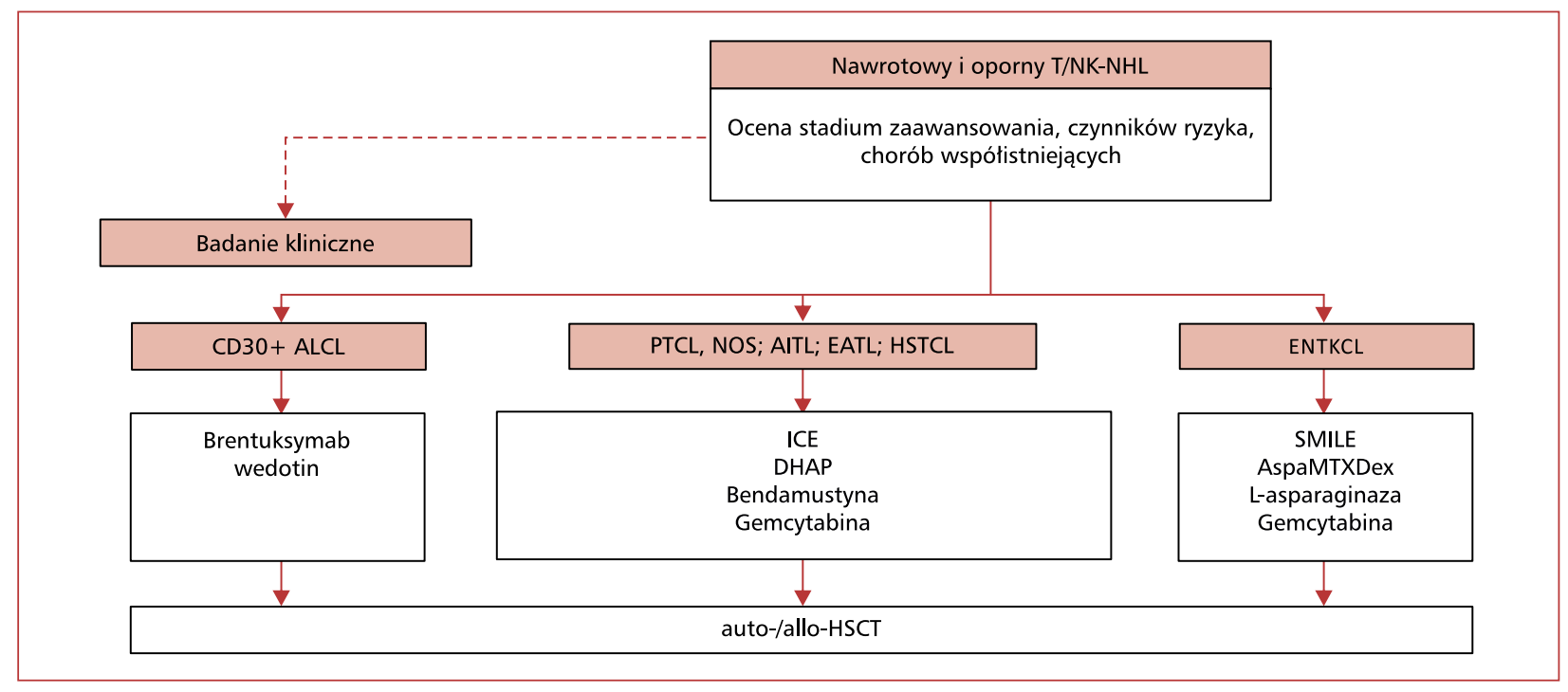

Rycina 2. Algorytm leczenia drugiej i kolejnej linii u chorych na nawrotowe i oporne postaci chłoniaków z dojrzałych komórek T i NK (naturalnej cytotoksyczności) o pierwotnej lokalizacji w węzłach chłonnych i/lub innych narządach (T/NK-NHL); ALCL — chłoniak z dużych komórek anaplastyczny; PTCL, NOS — chłoniak z obwodowych komórek T, bliżej nieokreślony; AITL — chłoniak z komórek T angioimmunoblastyczny; EATL — chłoniak z komórek T związany z enteropatią; HSTL — chłoniak z komórek T wątrobowo-śledzionowy; ENKTCL — pozawęzłowy chłoniak z komórek NK/T typu nosowego; ICE - etopozyd, ifosfamid, cisplatyna; DHAP — deksametazon, cytarabina, cisplatyna; SMILE — steroid (deksametazon), metotreksat, ifosfamid, L-asparaginaza, etopozyd; AspaMTXDex - L-asparaginaza, metotreksat, deksametazon; allo-HSCT — przeszczepienie allogenicznych krwiotwórczych komórek macierzystych; auto-HSCT — przeszczepienie autologicznych krwiotwórczych komórek macierzystych

Figure 2. Treatment algorithm of patients with relapsed or refractory mature T and NK (natural killers) cell lymphomas of primary nodal or extranodal localization (T/NK-NHL); ALCL — anaplastic large cell lymphoma; PTCL, NOS — peripheral T-cell lymphoma, not otherwise specified; AITL — angioimmunoblastic T-cell lymphoma; EATL — enteropathy-associated T-cell lymphoma; HSTL — hepatosplenic T-cell lymphoma; ENKTCL — extranodal NK/T-cell lymphoma, nasal type; ICE — etoposide, ifosfamide, cisplatine; DHAP — dexamethasone, cytarabine, cisplatine; SMILE — steroid [dexamethasone], methotrexate, ifosfamide, L-asparaginase, etoposide; AspaMTXDex — L-asparaginase, methotrexate, dexamethasone; allo-HSCT — allogeneic hematopoietic stem cell transplantation; auto-HSCT — autologous hematopoietic stem cell transplantation

\section{Ocena odpowiedzi na leczenie}

Międzynarodowa Grupa Robocza przyjęła w 2014 roku w Lugano ujednolicone kryteria oceny odpowiedzi na leczenie u chorych na chłoniaki (fluorodeoksyglukozo(FDG)-awidne i FDG-nieawidne) i te kryteria obecnie obowiązują u wszystkich chorych na T/NK-NHL (tab. 2) [18]. Oceny PET-CT dokonuje się na podstawie 5-punktowej wielkości wychwytu FDG w stosunku do puli naczyniowej śródpiersia na koniec leczenia (skala Deauville). Całkowita odpowiedź metaboliczna oznacza CR choroby nawet w przypadku utrzymywania się mas resztkowych w badaniu CT.

\section{Obserwacja po leczeniu}

Po zakończeniu leczenia chorych w CR powinno się oceniać $\mathrm{w}$ badaniach podmiotowym i przedmiotowym, a także na podstawie badań dodatkowych (morfologii krwi obwodowej, badań biochemicznych i aktywności LDH) co 3 miesiące w pierwszych 2 latach, co 6 miesięcy w trzecim roku, a następnie nie rzadziej niż raz na rok lub wtedy, gdy pojawią się uzasadnione wskazania kliniczne. Kontrolne wykonywanie badań PET-CT nie jest wskazane.

\section{Rokowanie}

Rokowanie u chorych na T/NK-NHL zależy przede wszystkim od podtypu histopatologicznego, stopnia zaawansowania choroby i czynników rokowniczych. Analiza danych z rejestrów ITCP i BCCA (British Columbia Cancer Agency) wskazuje, że w podtypie ALCL ALK(+) 5-letni PFS wynosi około $60 \%$, a OS - 70\% [40]. W przypadku podtypów PTLC, NOS, AITL i ALCL ALK(-) odsetki 5-letnich PFS wynoszą odpowiednio 20-30\%, 13-18\% 
Tabela 2. Pięciopunktowa skala pozytonowej tomografii emisyjnej (PET) (kryteria Deuville) (źródła [18, 20])

Table 2. Five-point positron emission tomography (PET) scale (Deuville criteria) (sources [18, 20])

\begin{tabular}{|l|l|}
\hline Punkty & Wynik badania PET — wychwyt FDG \\
\hline 1 & Bez wychwytu FDG powyżej tła \\
\hline 2 & Wychwyt FDG poniżej lub równy wychwytowi śródpiersia \\
\hline 3 & Wychwyt FDG powyżej wychwytu śródpiersia, ale poniżej lub równy z wychwytem wątroby \\
\hline 4 & Wychwyt FDG umiarkowany, powyżej wychwytu wątroby \\
\hline 5 & Wychwyt FDG znacznie wyższy od wychwytu wątroby \\
\hline
\end{tabular}

FDG - fluorodeoksyglukoza

i $28-36 \%$, a OS - 30-35\%, 32-36\% i $34-49 \%$ [32, 36, 40, 104]. Jeśli występował nie więcej niż 1 czynnik obciążający rokowanie według IPI, to odsetki 5-letnich OS, zależnie od podtypu histopatologicznego, wynosiły $44-90 \%$, a w przypadku wysokiego ryzyka (IPI $>2$ ) nie przekraczały $33 \%$ $[32,36,40,104]$.

\section{Szczególne sytuacje kliniczne}

\section{Białaczka/chłoniak z komórek T dorosłych}

Jest to nowotwór $z$ komórek T występujący endemicznie w Japonii, Korei, Nowej Gwinei, Afryce, na Wyspach Karaibskich i w Ameryce Południowej. Mediana wieku zachorowania wynosi 62 lata. Główną rolę patogenetyczną w tej chorobie odgrywa ludzki wirus T-limfotropowy 1 (HTLV-1, human T-cell lymphotropic virus 1), integrujący się $z$ limfocytami CD4+ [1, 3]. Zakażenie następuje drogą płciową, poprzez mleko matki lub krew. Ujawnienie procesu nowotworowego występuje u około 1/2000 nosicieli wirusa. W badaniu cytologicznym krwi obwodowej stwierdza się zwiększoną limfocytozę, z obecnością tak zwanych komórek kwiatowych o charakterystycznych jądrach $z$ głębokimi wcięciami. Immunofenotypowo przeważają dojrzałe limfocyty T, wykazujące ekspresję antygenów CD2, CD3, CD5, CD4 i rzadko CD8. Charakterystyczna jest obecność antygenu CD25, odpowiadającego łańcuchowi alfa receptora dla interleukiny 2 . Badanie kariotypu komórek chłoniakowych nie wykazuje charakterystycznych zaburzeń, a najczęściej obserwowanymi nieprawidłowościami są trisomia 7, 6q- i 14q+, mutacje TP53 [1]. Niezbędnym kryterium diagnostycznym dla ATLL jest wykazanie obecności genomu wirusowego $\mathrm{w}$ badaniach molekularnych lub stwierdzenie wysokiego miana przeciwciał anty-HTLV-1 [1]. Klinicznie ATLL rozpoczyna się zwykle zajęciem skóry i powiększeniem węzłów chłonnych. Chłoniak może również naciekać narządy wewnętrzne, w tym przede wszystkim śledzionę, wątrobę, płuca i OUN. Zmiany osteolityczne i hieperkalcemię obserwuje się u około $30 \%$ chorych. Charakterystyczne są głębokie niedobory odporności, przebiegające $z$ zakażeniami oportunistycznymi, wirusowymi i grzybiczymi. Choroba może mieć postać ostrą (57\%) przebiegającą z obrazem białaczkowym (wysoka limfocytoza), uogólnionym naciekaniem narządów wewnętrznych, zmianami kostnymi i hiperkalcemią. Postać chłoniakowa (19\%) charakteryzuje się uogólnioną limfadenopatią, ale bez naciekania innych narządów i zajęcia krwi obwodowej [1]. Obie postaci cechuje znaczna dynamika choroby; odsetek uzyskiwanych odpowiedzi na CTH (CHOP-14, VCAP [winkrystyna, cyklofosfamid, doksorubicyna, prednizon]/AMP [doksorubicyna, ranimustyna, prednizon]/VECP [windezyna, etopozyd, karboplatyna, prednizon]), w tym konsolidację za pomocą auto-/allo-HSCT, nie przekracza 60-70\% (3-letni OS 13-24\%) [105]. U większości chorych dochodzi do szybkiej progresji lub nawrotu choroby, mediana czasu przeżycia wynosi odpowiednio 6 i 10 miesięcy w przypadku postaci ostrej i chłoniakowej $[1,105]$.

W przeciwieństwie do postaci ostrej i chłoniakowej postać przewlekła ATLL (19\%) charakteryzuje się tylko nieznacznie podwyższoną limfocytozą i limfadenopatią, a niekiedy także zajęciem skóry i płuc [1]. Nie obserwuje się w tej postaci naciekania innych narządów wewnętrznych ani zmian kostnych czy hiperkalcemii. Poza profilaktyką i leczeniem zakażeń, przez dłuższy czas nie wymaga ona leczenia przeciwnowotworowego. Czas przeżycia chorych jest istotnie dłuższy niż chorych $z$ postaciami ostrą i chłoniakową ATLL (mediana wynosi 2 lata), ale nie ma dowodów na to, że leczenie cytostatyczne wydłuża go jeszcze bardziej. Jak dotąd, najlepsze wyniki leczenia uzyskano w grupie chorych leczonych interferonem alfa (IFN $\alpha$ ) w połączeniu z zidowudyną (70-90\% ORR) [1]. Postać tląca się ATLL (5\%) przebiega $z$ zajęciem skóry i zwykle nie wymaga leczenia. Postaci przewlekła 
i tląca się mogą transformować do postaci ostrej po różnym okresie trwania choroby [1].

\section{Pozawęzłowy chłoniak z komórek NK/T typu nosowego}

Pozawęzłowy chłoniak $z$ komórek NK/T typu nosowego jest rzadkim chłoniakiem, występującym przede wszystkim w Azji i Amerykach Środkowej i Poludniowej [3, 26]. Chorują najczęściej mężczyźni (3:1), w średnim i starszym wieku (mediana zachorowania 50-60 lat). Zachorowanie jest zwykle poprzedzone infekcją EBV lub/i stanem przewlekłej immunosupresji, ma zazwyczaj charakter ograniczony, ale przebiegający $z$ destrukcją okolicznych tkanek. Należą do nich struktury nosa i zatok przynosowych, a także skóry, przewodu pokarmowego, układu oddechowego, nerek, jąder i oczodołu. Zajęcie obwodowych węzłów chłonnych, szpiku i krwi obwodowej należy do rzadkości. W takich przypadkach różnicowanie $z$ agresywną białaczką $z$ komórek NK może być trudne. W preparatach histopatologicznych ENKTCL nacieki chłoniakowe są zlokalizowane wokół proliferujących naczyń, często $z$ obecnością rozległej martwicy powstałej wskutek zamykania światła drobnych naczyń przez komórki nowotworowe. Komórki chłoniakowe charakteryzuje ekspresja antygenów T-komórkowych, w tym $\mathrm{CD} 2+, \mathrm{CD} 5+/-, \mathrm{CD} 7+/-$ i często CD4+ i CD8+. Zwykle nie występuje antygen CD3, natomiast często stwierdza się ekspresję CD56. W komórkach chłoniakowych w większości przypadków stwierdza się obecność DNA EBV. Miano kopii DNA EBV we krwi leczonych chorych służy jako biomarker odpowiedzi na leczenie, dlatego zaleca sie jego monitorowanie w tym celu [24]. Postępowaniem $z$ wyboru w przypadkach choroby ograniczonej (CS I-II) jest zastosowanie IS-RT w dawce 50 Gy $[106,107]$. W celu systemowej kontroli choroby zaleca się uzupełniającą CTH 3 cyklami DeVIC (deksametazon, etopozyd, ifosfamid, karboplatyna) lub według protokołu koreańskiego obejmującego monoterapię cisplatyną $z$ następczymi 3 cyklami VIPD (etopozyd, ifosfamid, cisplatyna, deksametazon) $[26,108,109]$. U chorych w starszym wieku lub w złym stanie ogólnym zaleca się jedynie radioterapię. Odsetek remisji pozostaje wysoki, ale miejscowe nawroty są częste $(>50 \%)$, $z$ tendencją do rozsiewu do innych narządów $(>25 \%)$ [24, 110]. Sekwencyjna radiochemioterapia pozwala na uzyskanie 5-letniego OS na poziomie około 70\%. W przypadku choroby zaawansowanej (CS III-IV) oraz w okresie nawrotów stosuje się skojarzone leczenie radioterapią i protokoły CTH zawierające L-asparaginazę [24, 111]. Grupa robo- cza The NK Cell Tumor Study wykazała w badaniu klinicznym SMILE bardzo wysoką skuteczność schematu zawierającego steroidy, metotreksat, ifosfamid, L-asparaginazę i etopozyd, uzyskując 79\% ORR i 3-letni OS na poziomie 50\% [112]. Francuska Groupe d'Étude des Lymphomes de l'Adulte (GELA) i GOELAMS potwierdzily wysoką skuteczność schematu AspaMTXDex (L-asparaginaza, metotreksat, deksametazon) w nawrotowej postaci ENKTCL, uzyskując 74\% ORR i 47\% 1-roczny OS, choć w pierwszej linii leczenia wyniki nie były już tak dobre jak po zastosowaniu protokołu SMILE [113]. Klinicznym problemem w dłuższym stosowaniu L-asparaginazy pozostaje nadwrażliwość na lek; prawie u wszystkich leczonych chorych można wykryć przeciwciała przeciwko asparaginazie. Protokoły oparte na antracyklinie (CHOP i podobne schematy) są nieskuteczne [114]. Rola auto-HSCT jako konsolidacji początkowej odpowiedzi, zważywszy na opisane wyniki, pozostaje dyskusyjna. Zaleca się jej przeprowadzenie jako konsolidacji pierwszej $\mathrm{CR}$ i w nawrocie. U chorych starszych i w złym stanie ogólnym zaleca się L-asparaginazę w monoterapii albo zmodyfikowane protokoły AspaMTXDex lub SMILE [24, 115]. W przypadku nawrotu konieczne jest przeprowadzenie biopsji weryfikującej, ze wzgledu na duży odsetek fałszywie dodatnich wyników badania PET, które mogą odpowiadać wrzodziejacym zmianom zapalnym. Wybór leczenia ratunkowego zależy od rodzaju postępowania i uzyskanej odpowiedzi na leczenie pierwszej linii. W przypadku nawrotów wczesnych $(<1$ roku), po leczeniu $z$ wykorzystaniem protokołów opartych na antracyklinach, zaleca się schematy zawierające L-asaparaginazę. U chorych leczonych od początku według schematów zawierających L-asparaginazę zaleca się CTH $z$ gemcytabiną, na przykład GELOX (gemcytabina, L-asparaginaza, oksaliplatyna) [116]. W obu przypadkach rekomenduje się konsolidację $z$ wykorzystaniem auto- lub/i allo-HSCT [26].

\section{Chłoniak z komórek T}

\section{związany $z$ enteropatią}

Jest to rzadko występujący chłoniak obejmujący jelito cienkie [3]. Jego wystąpienie poprzedzają zwykle objawy glutenozależnego zespołu złego wchłaniania jelitowego, biegunka, bóle brzucha i postępujące zmniejszenie masy ciała, choć zachorowania na EATL nie zawsze są poprzedzone chorobą trzewną. Zachorowania dotyczą osób w wieku dorosłym (mediana 57 lat) i rzadko są konsekwencją zachorowania na chorobę trzewną w dzieciństwie. Choroba dotyczy zwykle nosicieli 
antygenu HLA DQ2 lub 8. Naciek chłoniakowy wywodzi się ze śródnabłonkowych dużych, atypowych limfocytów T występujących w otoczeniu licznych komórek odczynowych, w tym histiocytów, komórek plazmatycznych i eozynofilów. Komórki chłoniakowe wykazują ekspresję antygenów CD3 i CD7 i zwykle nie mają antygenów CD4 ani CD8. $\mathrm{W}$ miarę progresji choroby naciek nowotworowy szerzy się przez ciągłość na całą śluzówkę jelit, otaczającą sieć i regionalne węzły chłonne. Zmiany w przewodzie pokarmowym są wieloogniskowei mają postać owrzodzeń, łatwo krwawiących i ulegających perforacji. Dochodzi do zaniku kosmków błony śluzowej jelita cienkiego i znacznie nasilonych objawów zaburzeń wchłaniania jelitowego. Mimo intensywnego odżywiania pozajelitowego i diety bezglutenowej chorzy są zwykle wyniszczeni i w złym stanie ogólnym. W końcowych fazach choroby dochodzi do uogólnienia procesu chłoniakowego, głównie do wątroby. Powikłaniami choroby mogą być także niedrożność przewodu pokarmowego i śmiertelność spowodowana wieloogniskowymi i nawracającymi perforacjami przewodu pokarmowego [117]. Mimo prób stosowania różnych schematów CTH, w tym CHOP, CHOEP, IVE/MTX (ifosfamid, etopozyd, wysokodawkowany metotreksat), większość chorych wykazuje pierwotną oporność na leczenie lub wczesne wznowy choroby; odsetek chorych przeżywających 5 lat nie przekracza $20 \%$, a mediana OS wynosi 7 miesięcy. Protokół IVE/MTX z następczą konsolidają auto-HSCT pozwolił na uzyskanie lepszych 5-letnich odsetków PFS (52\%) i OS (60\%) [117]. Schemat CHOEP-14 $z$ auto-HSCT wydaje się także bardziej skuteczny od CHOP [38]. W retrospektywnej analizie danych $\mathrm{z}$ rejestru $E u$ ropean Group for Blood and Marrow Transplantation (EBMT) potwierdzono, że zastosowanie auto-HSCT jako konsolidacji CTH pierwszej linii pozwala na uzyskanie lepszych odpowiedzi, z 4-letnimi odsetkami PFS i OS na poziomie odpowiednio $54 \%$ i $59 \%$ [118]. W przypadku nawrotu zaleca się leczenie jak w innych podtypach T/NK-NHL, w tym $z$ wykorzystaniem auto- lub/i allo-HSCT.

\section{Chłoniak z komórek T wątrobowo- -śledzionowy}

Chłoniak $\mathrm{z}$ komórek $\mathrm{T}$ wątrobowo-śledzionowy (HSTL, hepatosplenic T-cell lymphoma) jest bardzo rzadką postacią chłoniaka, występującą głównie u młodych mężczyzn (mediana 34 lata) [119]. Często wiąże się ze stanem przewlekłej immunosupresji, w tym po przeszczepieniu narządów, ale nie udokumentowano związku etiopatogenetycznego HSTL $z$ zakażeniem EBV. Komórki chłoniakowe cechuje fenotyp limfocytów T $\gamma / \delta$ (CD4-, CD8-) $z$ obecnością antygenu CD3 i niekiedy CD56. Bardzo rzadko występuje wariant wywodzący się z limfocytów T $\alpha \beta(\mathrm{CD} 4+, \mathrm{CD} 8-$ lub CD4-, $\mathrm{CD} 8+$ ). Typowym zaburzeniem cytogenetycznym jest obecność izochromosomu 7q. Nacieki komórek chłoniakowych obejmują wątrobę i śledzionę oraz czasem szpik kostny [119]. Przebieg kliniczny charakteryzują obecność objawów ogólnych choroby, powiększenie wątroby i śledziony, niekiedy limfadenopatia i pancytopenia we krwi obwodowej [119]. Mimo początkowej dobrej odpowiedzi na leczenie splenektomią lub za pomocą CTH (analogi puryn, CHOP), alemtuzumabu i auto-HSCT remisje są krótkotrwałe, z 5-letnimi odsetkami PFS i OS nie przekraczającymi $10 \%$. Mediana czasu przeżycia chorych wynosi około 16 miesięcy [119, 120]. Pojedyncze dłuższe przeżycia obserwowano po allo-HSCT (5-letni OS 50\%), dlatego u każdego chorego po uzyskaniu remisji należy rozważyć konsolidację $z$ wykorzystaniem auto- lub/i allo-HSCT [119, 121, 122]. Zalecanymi protokołami leczenia pierwszej linii są: ICE, IVAC (ifosfamid, cytarabina, etopozyd) lub dose-dense CHOEP/EPOCH (etopozyd, winkrystyna, doksorubicyna, cyklofosfamid, prednizon) [38, 122]. W przypadku nawrotu zaleca się leczenie jak w innych podtypach T/NK-NHL, $\mathrm{w}$ tym $\mathrm{z}$ wykorzystaniem auto- lub/i allo-HSCT.

\section{Chłoniak z komórek T, angioimmunoblastyczny}

Jest rzadko występującym chłoniakiem (0,1/100 tys./rok nowych zachorowań), zwykle u osób starszych (mediana wieku 59-64 lata), z nieznaczną przewagą mężczyzn [3, 123]. Stwarza duże trudności diagnostyczne w różnicowaniu $z$ limfadenopatią odczynową ze względu na zróżnicowany obraz kliniczny przebiegający $z$ objawami ogólnymi choroby, towarzyszącymi zaburzeniami autoimmunizacyjnymi, powikłaniami infekcyjnymi oraz jednoczesną proliferacją monoklonalnych limfocytów T i mono- lub oligoklonalnych limfocytów B, w których zwykle obecny jest genom EBV. Struktura węzła chłonnego jest zatarta przez rozrost naczyń i polimorficzne nacieki z limfocytów T $(\mathrm{CD} 3+$, CD4+ i CD8-), skupienia komórek dendrytycznych (CD21+ i CD35+) w miejscu zanikowych ośrodków rozmnażania oraz liczne plazmocyty, neutrofile, eozynofile i komórki nabłonkowe. Charakterystycznymi zaburzeniami cytogenetycznymi w AITL są trisomie chromosomów 3 i 5, dodatkowy chromosom $\mathrm{X}$ oraz strukturalne aberracje w obrębie krótkiego ramienia chromosomu 1 [3]. Od początku choroby stwierdza się zaawansowany 
stan kliniczny, objawy ogólne, niespecyficzne zmiany skórne, uogólnioną limfadenopatię oraz skłonność do ciężko przebiegających zakażeń. Często dochodzi do zajęcia szpiku kostnego, wątroby, śledziony i narządów pozalimfatycznych, w tym przede wszystkim przewodu pokarmowego. Mogą wystąpić objawy zapalenia wielostawowego, zapalenia naczyń, autoimmunizacyjnego zapalenia tarczycy, obrzęki i przesięki do jam ciała. W badaniu morfologii krwi obwodowej są obecne limfopenia, eozynofilia i niedokrwistość, często o podłożu autoimmunohemolitycznym, rzadziej pancytopenia. U większości chorych stwierdza się poliklonalną hipergammaglobulinemię oraz obecność autoprzeciwciał, w tym ciepłych i zimnych aglutynin i krążących kompleksów immunologicznych $[3,123]$.

Nie ma jednoznacznych wytycznych dotyczących leczenia chorych na AITL. Wynika to po części z trudności diagnostycznych związanych $z$ różnicowaniem AITL $z$ limfadenopatią odczynową. $\mathrm{W}$ takich przypadkach leczenie rozpoczyna się zwykle od kortykosteroidów, które powodują ustąpienie objawów ogólnych choroby i limfadenopatii u większości chorych. W przypadku jednoznacznych cech potwierdzających rozpoznanie AITL podstawą leczenia jest strategia podobna jak $\mathrm{w}$ innych $\mathrm{T} /$ /NK-NHL [36, 45, 123-125]. Odpowiedzi uzyskuje się u większości chorych, ale są one krótkotrwałe (także po konsolidacji auto-HSCT), bez względu na rodzaj początkowej CTH (CHOP $v$. ACVBP [doksorubicyna, cyklofosfamid, windezyna, bleomycyna, prednizon] $v$. mBACOD [metotreksat, bleomycyna, doksorubicyna, cyklofosfamid, winkrystyna, deksametazon]), o czym świadczą dane uzyskane przez GELA na podstawie T-Cell Lymphoma Project $[36,123]$. Są doniesienia wskazujące na skuteczność - w monoterapii lub w połączeniu z CTH - lenalidomidu, inhibitorów HDAC, bortezomibu, alemtuzumabu i denileukin diftitox [49, 126-131]. Badania kliniczne III fazy nad skojarzonym leczeniem CHOP $z$ lenalidomidem (NCT01553786) i romidepsyną (NCT01796002) są realizowane. $\mathrm{W}$ przypadkach przebiegających $\mathrm{z}$ powikłaniami autoimmunizacyjnymi istnieją wskazania do leczenia immunosupresyjnego, $w$ tym podawania małych dawek metotreksatu i prednizonu, a także cyklosporyny. Rytuksymab - w monoterapii lub w połączeniu z CHOP (R-CHOP) - stosuje się $\mathrm{w}$ przypadkach przebiegających $\mathrm{z}$ cytopeniami autoimmunizacyjnymi i/lub obecnością w nacieku chłoniakowym wysokiego odsetka dużych komórek B CD20+. Całkowity odsetek uzyskiwanych odpowiedzi po R-CHOP wynosi $80 \%$, w tym $44 \%$ CR i 36\% PR, z medianą okresu odpowiedzi wynoszącą około 2 lat i 2-letnim OS na poziomie 62\% [132].

Wyniki leczenia chorych na AITL nie są dobre; odsetek uzyskiwanych CR wynosi około $50 \%$, ale nawroty występują często [36, 45, 123]. Mediana czasu przeżycia nie przekracza 3 lat, odsetek 5-letniego OS wynosi $30-35 \%$, w tym $44 \%$ w grupie niskiego i $24 \% \mathrm{w}$ grupie wysokiego ryzyka [36]. Większość chorych umiera $z$ powodu progresji choroby zasadniczej lub powikłań infekcyjnych.

\section{Chłoniak z dużych komórek anaplastyczny}

W klasyfikacji WHO z 2016 roku wyróżniono trzy podtypy ALCL, w tym dwie postaci systemowe (ALCL ALK + i ALCL ALK-) oraz pierwotną skórną ALCL (C-ALCL, primary cutaneous anaplastic large cell lymphoma) [4]. Około 60\% ALCL stanowią postaci ALK + o lepszym rokowaniu niż postaci ALK-, które i tak rokują korzystniej niż PTCL, NOS [40, 45]. Molekularnym markerem ALCL ALK+ jest translokacja $\mathrm{t}(2 ; 5)$ prowadząca do przeniesienia genu kodującego kinazę chłoniaka anaplastycznego (ALK, anaplastic lymphoma kinase) $z$ chromosomu $2 \mathrm{w}$ okolicę genu dla nukleofozminy (NPM, nucleophosmin) w obrębie chromosomu 5 , z powstaniem białka hybrydowego (NPM-ALK) wykazującego aktywność kinazy tyrozynowej. Obecność białka hybrydowego można wykazać za pomocą przeciwciał anty- $A L K$. Utkanie chłoniaka tworzą duże, polimorficzne komórki naciekające zatoki węzła, o różnokształtnych jądrach i wyraźnych jąderkach. Charakterystyczna jest obecność licznych granulocytów i makrofagów. Komórki chłoniakowe często przypominają komórki Reed-Sternberga i Hodgkina, choć nierzadko mogą imitować także komórki czerniaka lub nowotworów nabłonkowych. Niekiedy odsetek komórek chłoniakowych pozostaje bardzo niewielki, a obraz histopatologiczny jest zdominowany obecnością licznych histiocytów. Te przypadki wymagają różnicowania $z$ klasyczną postacią HL ubogą w limfocyty, histiocytozą oraz $z$ innymi nowotworami. Charakterystyczną cechą komórek ALCL, choć niespecyficzną, jest obecność na ich powierzchni antygenu CD30 (Ki-1). W większości przypadków komórki te charakteryzuje także obecność innych markerów aktywacyjnych limfocytów T, w tym CD25, CD71 i CD45. W około $50 \%$ przypadków stwierdza się również ekspresję antygenów grupowych krwi klas $\mathrm{H}$ i Y, wykrywanych za pomocą przeciwciała monoklonalnego BNH9. Postaci układowe charakteryzuje obecność na komórkach chłoniakowych antygenu EMA (epithelial membrane antigen), którego nie stwierdza się w C-ALCL. W tych ostatnich charakterystyczna 
jest natomiast ekspresja antygenu CLA (cutaneous lymphocyte antigen) [3].

W przeciwieństwie do C-ALCL, występującej głównie u osób starszych, ALCL ALK+ występuje u osób młodych (mediana 30 lat, z przewagą mężczyzn) lub w średnim wieku (ALK-) [40]. Postaci układowe przebiegają $z$ objawami ogólnymi choroby (75\%), uogólnioną limfadenopatią i zajęciem okolic pozawęzłowych, w tym skóry (20\%), kości i tkanek miękkich (17\%). Mimo to u większości chorych na ALCL ALK(+) rokowanie według IPI jest dobre ze względu na młody wiek, dobry stan ogólny i prawidłowe wartości LDH. Do rzadkości należy zajęcie szpiku kostnego i krwi obwodowej. Rokowanie w postaciach $\operatorname{ALK}(+)$ jest nie tylko lepsze niż w ALK(-), ale nawet lepsze niż rokowanie w chłoniakach rozlanych $z$ dużych komórek B w porównywalnych grupach ryzyka według IPI $[40,45$, 133]. Chemioterapia $6-8$ cyklami według programu CHOP-21 umożliwia uzyskanie remisji choroby u około $80 \%$ chorych. Dlatego standardem postępowania w ALCL ALK(+) jest odstąpienie od auto-HSCT jako konsolidacji pierwszej linii leczenia i pozostawienie tej opcji jedynie w przypadku nawrotów po uprzednim zastosowaniu drugiej linii leczenia na podstawie schematów zawierających BV i/ /lub związki platyny [45, 65]. Leczenie postaci ALK(-) powinno przebiegać według strategii przyjętej dla innych podtypów T/NK-NHLK.

Rzadka odmiana ALCL ALK(-) gruczołu piersiowego po wszczepieniu implantów ma zwykle łagodny przebieg (postać wysiękowa) i wymaga jedynie ich usunięcia — w każdym takim przypadku należy wykluczyć obecność miejscowego naciekania i/lub choroby układowej wymagających leczenia systemowego [4, 134, 135].

Przypadki C-ALCL charakteryzują się łagodnym przebiegiem, z 10-letnim odsetkiem przeżyć przekraczającym $90 \%$ [5]. W leczeniu pojedynczych zmian stosuje się wycięcie chirurgiczne lub radioterapię. W przypadku mnogich zmian skórnych stosuje się małe dawki metotreksatu lub radioterapię. Jeśli leczenie to jest nieskuteczne, to zaleca się systemowe leczenie pochodnymi retinoidów lub beksaroten. Ostatnie doniesienia wskazują na skuteczność brentuksymabu wedotin w leczeniu przypadków nawrotowych [5].

\section{Piśmiennictwo}

1. Tsukasaki K, Hermine O, Bazarbachi A, et al. Definition, prognostic factors, treatment, and response criteria of adult T-cell leukemia-lymphoma: a proposal from an international consensus meeting. J Clin Oncol. 2009; 27(3): 453-459, doi: 10.1200/ /JCO.2008.18.2428, indexed in Pubmed: 19064971.
2. Tse E, Kwong YL. The diagnosis and management of NK/T-cell lymphomas. J Hematol Oncol. 2017; 10(1): 85, doi: 10.1186/ /s13045-017-0452-9, indexed in Pubmed: 28410601.

3. Swerdlow SH. WHO classification of tumours of haematopoietic and lymphoid tissues. Fourth edition. IARC, 2008.

4. Swerdlow SH, Campo E, Pileri SA, et al. The 2016 revision of the World Health Organization classification of lymphoid neoplasms. Blood. 2016; 127(20): 2375-2390.

5. Willemze R, Hodak E, Zinzani PL, et al. Primary cutaneous lymphomas: ESMO clinical practice guidelines for diagnosis, treatment and follow-up. Ann Oncol. 2013; 24(Suppl 6): v149-v154.

6. Suzuki R, Takeuchi K, Ohshima K, et al. Extranodal NK/T-cell lymphoma: diagnosis and treatment cues. Hematol Oncol. 2008; 26(2): 66-72, doi: 10.1002/hon.847, indexed in Pubmed: 18283711.

7. de Leval L, Gaulard P. Pathology and biology of peripheral T-cell lymphomas. Histopathology. 2011; 58(1): 49-68, doi: 10.1111/j.1365-2559.2010.03704.x, indexed in Pubmed: 21261683.

8. Vose J, Armitage J, Weisenburger D, et al. International T-Cell Lymphoma Project. International peripheral T-cell and natural killer/T-cell lymphoma study: pathology findings and clinical outcomes. J Clin Oncol. 2008; 26(25): 4124-4130, doi: 10.1200/ /JCO.2008.16.4558, indexed in Pubmed: 18626005.

9. Gaulard P, de Leval L. Pathology of peripheral T-cell lymphomas: where do we stand? Semin Hematol. 2014; 51(1): 5-16, doi: 10.1053/j.seminhematol.2013.11.003, indexed in Pubmed: 24468311.

10. Tse E, Kwong YL. Diagnosis and management of extranodal NK/T cell lymphoma nasal type. Expert Rev Hematol. 2016; 9(9): 861-871, doi: 10.1080/17474086.2016.1206465, indexed in Pubmed: 27347812.

11. Coiffier B, Brousse N, Peuchmaur M, et al. Peripheral T-cell lymphomas have a worse prognosis than B-cell lymphomas: a prospective study of 361 immunophenotyped patients treated with the LNH-84 regimen. The GELA (Groupe d'Etude des Lymphomes Agressives). Ann Oncol. 1990; 1(1): 45-50, indexed in Pubmed: 1706610.

12. Sakata Ki, Fuwa N, Kodaira T, et al. Analyses of dose-response in radiotherapy for patients with mature T/NK-cell lymphomas according to the WHO classification. Radiother Oncol. 2006; 79(2): 179-184, doi: 10.1016/j.radonc.2006.03.014, indexed in Pubmed: 16644044.

13. Pedersen MB, Hamilton-Dutoit SJ, Bendix K, et al. Evaluation of clinical trial eligibility and prognostic indices in a population-based cohort of systemic peripheral T-cell lymphomas from the Danish Lymphoma Registry. Hematol Oncol. 2015; 33(4): 120-128, doi: 10.1002/hon.2153, indexed in Pubmed: 25052551.

14. d'Amore F, Gaulard P, Trümper L, et al. ESMO Guidelines Committee. Peripheral T-cell lymphomas: ESMO clinical practice guidelines for diagnosis, treatment and follow-up. Ann Oncol. 2015; 26 Suppl 5: v108-v115, doi: 10.1093/annonc/mdv201, indexed in Pubmed: 26314772.

15. Asano N, Suzuki R, Kagami Y, et al. Clinicopathologic and prognostic significance of cytotoxic molecule expression in nodal peripheral T-cell lymphoma, unspecified. Am J Surg Pathol. 2005; 29(10): 1284-1293, doi: 10.1097/01.pas.0000173238.17331.6b, indexed in Pubmed: 16160469.

16. de Leval L, Rickman DS, Thielen C, et al. The gene expression profile of nodal peripheral T-cell lymphoma demonstrates a molecular link between angioimmunoblastic T-cell lymphoma (AITL) and follicular helper T (TFH) cells. Blood. 2007; 109(11): 
4952-4963, doi: 10.1182/blood-2006-10-055145, indexed in Pubmed: 17284527 .

17. Iqbal J, Weisenburger DD, Greiner TC, et al. International Peripheral T-Cell Lymphoma Project. Molecular signatures to improve diagnosis in peripheral T-cell lymphoma and prognostication in angioimmunoblastic T-cell lymphoma. Blood. 2010; 115(5): 1026-1036, doi: 10.1182/blood-2009-06-227579, indexed in Pubmed: 19965671.

18. Cheson BD, Fisher RI, Barrington SF, et al. Alliance, Australasian Leukaemia and Lymphoma Group, Eastern Cooperative Oncology Group, European Mantle Cell Lymphoma Consortium, Italian Lymphoma Foundation, European Organisation for Research, Treatment of Cancer/Dutch Hemato-Oncology Group, Grupo Español de Médula Ósea, German High-Grade Lymphoma Study Group, German Hodgkin's Study Group, Japanese Lymphorra Study Group, Lymphoma Study Association, NCIC Clinical Trials Group, Nordic Lymphoma Study Group, Southwest Oncology Group, United Kingdom National Cancer Research Institute. Recommendations for initial evaluation, staging, and response assessment of Hodgkin and non-Hodgkin lymphoma: the Lugano classification. J Clin Oncol. 2014; 32(27): 3059-3068, doi: 10.1200/ /JCO.2013.54.8800, indexed in Pubmed: 25113753.

19. Meignan M, Gallamini A, Meignan M, et al. Report on the First International Workshop on Interim-PET-Scan in Lymphoma. Leuk Lymphoma. 2009; 50(8): 1257-1260, doi: 10.1080/10428190903040048, indexed in Pubmed: 19544140.

20. Barrington SF, Mikhaeel NG, Kostakoglu L, et al. Role of imaging in the staging and response assessment of lymphoma: consensus of the International Conference on Malignant Lymphomas Imaging Working Group. J Clin Oncol. 2014; 32(27): 3048-3058, doi: 10.1200/JCO.2013.53.5229, indexed in Pubmed: 25113771.

21. Barrington SF, Qian W, Somer EJ, et al. Concordance between four European centres of PET reporting criteria designed for use in multicentre trials in Hodgkin lymphoma. Eur J Nucl Med Mol Imaging. 2010; 37(10): 1824-1833, doi: 10.1007/s00259-010-1490-5, indexed in Pubmed: 20505930.

22. Quarles van Ufford $\mathrm{H}$, Hoekstra $\mathrm{O}$, de Haas $\mathrm{M}$, et al. On the added value of baseline FDG-PET in malignant lymphoma. Mol Imaging Biol. 2010; 12(2): 225-232, doi: 10.1007/s11307-009-0259-3, indexed in Pubmed: 19809855.

23. Chan WK, Au WY, Wong CYO, et al. Metabolic activity measured by F-18 FDG PET in natural killer-cell lymphoma compared to aggressive B- and T-cell lymphomas. Clin Nucl Med. 2010; 35(8): 571-575, doi: 10.1097/RLU.0b013e3181e4dcbf, indexed in Pubmed: 20631501.

24. Kwong YL, Anderson BO, Advani R, et al. Asian Oncology Summit. Management of T-cell and natural-killer-cell neoplasms in Asia: consensus statement from the Asian Oncology Summit 2009. Lancet Oncol. 2009; 10(11): 1093-1101, doi: 10.1016/ /S1470-2045(09)70265-7, indexed in Pubmed: 19880063.

25. Zhou X, Lu K, Geng L, et al. Utility of PET/CT in the diagnosis and staging of extranodal natural killer/T-cell lymphoma: a systematic review and meta-analysis. Med (Balt). 2014; 93(28): e258, doi: 10.1097/MD.0000000000000258, indexed in Pubmed: 25526450.

26. Tse E, Kwong YL. How I treat NK/T-cell lymphomas. Blood. 2013; 121(25): 4997-5005, doi: 10.1182/blood-2013-01-453233, indexed in Pubmed: 23652805.

27. Moon SH, Cho SK, Kim WS, et al. The role of ${ }^{18}$ F-FDG PET/CT for initial staging of nasal type natural killer/T-cell lymphoma: a comparison with conventional staging methods. J Nucl Med.
2013; 54(7): 1039-1044, doi: 10.2967/jnumed.112.113399, indexed in Pubmed: 23658217.

28. Tsukamoto N. The usefulness of (18)F-fluorodeoxyglucose positron emission tomography ((18)F-FDG-PET) and a comparison of (18)F-FDG-pet with (67)gallium scintigraphy in the evaluation of lymphoma: relation to histologic subtypes based on the World Health Organization classification. Cancer. 2007; 110(3): 652-659.

29. Khong PL, Pang C, Liang R, et al. Fluorine-18 fluorodeoxyglucose positron emission tomography in mature T-cell and natural killer cell malignancies. Ann Hematol. 2008; 87(8): 613-621, doi: 10.1007/s00277-008-0494-8.

30. International Non-Hodgkin's Lymphoma Prognostic Factors Project. A predictive model for aggressive non-Hodgkin's lymphoma. N Engl J Med. 1993; 329(14): 987-994, doi: 10.1056/ /NEJM199309303291402, indexed in Pubmed: 8141877.

31. Suzumiya J, Ohshima K, Tamura K, et al. International Peripheral T-Cell Lymphoma Project. The International Prognostic Index predicts outcome in aggressive adult T-cell leukemia/lymphoma: analysis of 126 patients from the International Peripheral T-Cell Lymphoma Project. Ann Oncol. 2009; 20(4): 715-721, doi: 10.1093/annonc/mdn696, indexed in Pubmed: 19150954.

32. Weisenburger DD, Savage KJ, Harris NL, et al. International Peripheral T-cell Lymphoma Project. Peripheral T-cell lymphoma, not otherwise specified: a report of 340 cases from the International Peripheral T-cell Lymphoma Project. Blood. 2011; 117(12): 3402-3408, doi: 10.1182/blood-2010-09-310342, indexed in Pubmed: 21270441.

33. Gutiérrez-García G, García-Herrera A, Cardesa T, et al. Comparison of four prognostic scores in peripheral T-cell lymphoma. Ann Oncol. 2011; 22(2): 397-404, doi: 10.1093/annonc/mdq359, indexed in Pubmed: 20631009.

34. Gallamini A. Peripheral T-cell lymphoma unspecified (PTCL-U): a new prognostic model from a retrospective multicentric clinical study. Blood. 2004; 103(7): 2474-2479, doi: 10.1182/ /blood-2003-09-3080.

35. Went P, Agostinelli C, Gallamini A, et al. Marker expression in peripheral T-cell lymphoma: a proposed clinical-pathologic prognostic score. J Clin Oncol. 2006; 24(16): 2472-2479, doi: 10.1200/ /JCO.2005.03.6327, indexed in Pubmed: 16636342.

36. Federico M, Rudiger T, Bellei M, et al. Clinicopathologic characteristics of angioimmunoblastic T-cell lymphoma: analysis of the international peripheral T-cell lymphoma project. J Clin Oncol. 2013; 31(2): 240-246, doi: 10.1200/JCO.2011.37.3647, indexed in Pubmed: 22869878.

37. Ellin F, Landström J, Jerkeman M, et al. Real-world data on prognostic factors and treatment in peripheral T-cell lymphomas: a study from the Swedish Lymphoma Registry. Blood. 2014; 124(10): 1570-1577, doi: 10.1182/blood-2014-04-573089, indexed in Pubmed: 25006130.

38. d'Amore F, Relander T, Lauritzsen GF, et al. Up-front autologous stem-cell transplantation in peripheral T-cell lymphoma: NLG-T-01. J Clin Oncol. 2012; 30(25): 3093-3099, doi: 10.1200/ /JCO.2011.40.2719, indexed in Pubmed: 22851556.

39. Suzuki R, Yamaguchi M, Izutsu K, et al. NK-cell Tumor Study Group. Prospective measurement of Epstein-Barr virus-DNA in plasma and peripheral blood mononuclear cells of extranodal NK/T-cell lymphoma, nasal type. Blood. 2011; 118(23): 6018-6022, doi: 10.1182/blood-2011-05-354142, indexed in Pubmed: 21984805.

40. Savage KJ. ALK- anaplastic large-cell lymphoma is clinically and immunophenotypically different from both ALK+ ALCL and peripheral T-cell lymphoma, not otherwise specified: report from 
the International Peripheral T-Cell Lymphoma Project. Blood. 2008; 111(12): 5496-5504.

41. Escalón MP, Liu NS, Yang Y, et al. Prognostic factors and treatment of patients with T-cell non-Hodgkin lymphoma: the M.D. Anderson Cancer Center experience. Cancer. 2005; 103(10): 2091-2098, doi: 10.1002/cncr.20999, indexed in Pubmed: 15816054.

42. Simon A, Peoch M, Casassus P, et al. Upfront VIP-reinforced-AB-VD (VIP-rABVD) is not superior to $\mathrm{CHOP} / 21$ in newly diagnosed peripheral $\mathrm{T}$ cell lymphoma. Results of the randomized phase III trial GOELAMS-LTP95. Br J Haematol. 2010; 151(2): 159-166, doi: 10.1111/j.1365-2141.2010.08329.x, indexed in Pubmed: 20738307.

43. Pfreundschuh M. Two-weekly or 3-weekly CHOP chemotherapy with or without etoposide for the treatment of elderly patients with aggressive lymphomas: results of the NHL-B2 trial of the DSHNHL. Blood. 2004; 104(3): 634-641, doi: 10.1182/ /blood-2003-06-2095.

44. Pfreundschuh M, Trümper L, Kloess M, et al. German High-Grade Non-Hodgkin's Lymphoma Study Group. Two-weekly or 3-weekly CHOP chemotherapy with or without etoposide for the treatment of young patients with good-prognosis (normal LDH) aggressive lymphomas: results of the NHL-B1 trial of the DSHNHL. Blood. 2004; 104(3): 626-633, doi: 10.1182/ /blood-2003-06-2094, indexed in Pubmed: 14982884.

45. Schmitz N, Trümper L, Ziepert M, et al. Treatment and prognosis of mature T-cell and NK-cell lymphoma: an analysis of patients with T-cell lymphoma treated in studies of the German High-Grade Non-Hodgkin Lymphoma Study Group. Blood. 2010; 116(18): 3418-3425, doi: 10.1182/blood-2010-02-270785, indexed in Pubmed: 20660290.

46. Mercadal S, Briones J, Xicoy B, et al. Grup per l'Estudi dels Limfomes de Catalunya I Balears (GELCAB). Intensive chemotherapy (high-dose CHOP/ESHAP regimen) followed by autologous stem-cell transplantation in previously untreated patients with peripheral T-cell lymphoma. Ann Oncol. 2008; 19(5): 958-963, doi: 10.1093/annonc/mdn022, indexed in Pubmed: 18303032.

47. Reimer P, Rüdiger T, Geissinger E, et al. Autologous stem-cell transplantation as first-line therapy in peripheral T-cell lymphomas: results of a prospective multicenter study. J Clin Oncol. 2009; 27(1): 106-113, doi: 10.1200/JCO.2008.17.4870, indexed in Pubmed: 19029417.

48. Rodríguez J, Conde E, Gutiérrez A, et al. 'Grupo Español de Linfomas/Trasplante Autólogo de Médula Osea' (GEL-TAMO). Frontline autologous stem cell transplantation in high-risk peripheral T-cell lymphoma: a prospective study from The Gel-Tamo Study Group. Eur J Haematol. 2007; 79(1): 32-38, doi: 10.1111/j.1600-0609.2007.00856.x, indexed in Pubmed: 17598836.

49. Corradini P, Vitolo U, Rambaldi A, et al. Intensified chemo-immunotherapy with or without stem cell transplantation in newly diagnosed patients with peripheral T-cell lymphoma. Leukemia. 2014; 28(9): 1885-1891, doi: 10.1038/leu.2014.79, indexed in Pubmed: 24662801.

50. Zinzani PL. High-dose therapy and stem cell transplantation. Semin Hematol. 2010; 47(Suppl 1): S15-S17, doi: 10.1053/j.seminhematol.2010.01.017, indexed in Pubmed: 20359581.

51. Feyler S, Prince HM, Pearce R, et al. The role of high-dose therapy and stem cell rescue in the management of T-cell malignant lymphomas: a BSBMT and ABMTRR study. Bone Marrow Transplant. 2007; 40(5): 443-450, doi: 10.1038/sj.bmt.1705752, indexed in Pubmed: 17589529.

52. Mehta N, Maragulia JC, Moskowitz A, et al. A retrospective analysis of peripheral T-cell lymphoma treated with the intention to transplant in the first remission. Clin Lymphoma Myeloma Leuk. 2013; 13(6): 664-670, doi: 10.1016/j.clml.2013.07.005, indexed in Pubmed: 24035712.

53. O'Connor OA, Horwitz S, Hamlin P, et al. Phase II-I-II study of two different doses and schedules of pralatrexate, a high-affinity substrate for the reduced folate carrier, in patients with relapsed or refractory lymphoma reveals marked activity in T-cell malignancies. J Clin Oncol. 2009; 27(26): 4357-4364, doi: 10.1200/ /JCO.2008.20.8470, indexed in Pubmed: 19652067.

54. O'Connor OA, Pro B, Pinter-Brown L, et al. Pralatrexate in patients with relapsed or refractory peripheral T-cell lymphoma: results from the pivotal PROPEL study. J Clin Oncol. 2011; 29(9): 1182-1189, doi: 10.1200/JCO.2010.29.9024, indexed in Pubmed: 21245435.

55. Coiffier B, Pro B, Prince HM, et al. Results from a pivotal, open-label, phase II study of romidepsin in relapsed or refractory peripheral T-cell lymphoma after prior systemic therapy. J Clin Oncol. 2012; 30(6): 631-636, doi: 10.1200/JCO.2011.37.4223, indexed in Pubmed: 22271479.

56. Piekarz RL, Frye R, Prince HM, et al. Phase 2 trial of romidepsin in patients with peripheral T-cell lymphoma. Blood. 2011; 117(22): 5827-5834, doi: 10.1182/blood-2010-10-312603, indexed in Pubmed: 21355097.

57. Dupuis J, Morschhauser F, Ghesquières H, et al. Combination of romidepsin with cyclophosphamide, doxorubicin, vincristine, and prednisone in previously untreated patients with peripheral T-cell lymphoma: a non-randomised, phase 1b/2 study. Lancet Haematol. 2015; 2(4): e160-e165, doi: 10.1016/s2352-3026(15)00023-x.

58. Duvic M, Dummer R, Becker JC, et al. Panobinostat activity in both bexarotene-exposed and -naïve patients with refractory cutaneous T-cell lymphoma: results of a phase II trial. Eur J Cancer. 2013; 49(2): 386-394, doi: 10.1016/j.ejca.2012.08.017, indexed in Pubmed: 22981498.

59. Pro B, Advani R, Brice P, et al. Brentuximab vedotin (SGN-35) in patients with relapsed or refractory systemic anaplastic large-cell lymphoma: results of a phase II study. J Clin Oncol. 2012; 30(18): 2190-2196, doi: 10.1200/JCO.2011.38.0402, indexed in Pubmed: 22614995.

60. Fanale MA. Brentuximab vedotin administered concurrently with multi-agent chemotherapy as frontline treatment of ALCL and other CD30-positive mature T-cell and NK-cell lymphomas. Blood. 2012; 120(21): 60-60.

61. Younes A, Bartlett NL, Leonard JP, et al. Brentuximab vedotin (SGN-35) for relapsed CD30-positive lymphomas. N Engl J Med. 2010; 363(19): 1812-1821, doi: 10.1056/NEJMoa1002965, indexed in Pubmed: 21047225.

62. Zinzani PL, Venturini F, Stefoni V, et al. Gemcitabine as single agent in pretreated T-cell lymphoma patients: evaluation of the long-term outcome. Ann Oncol. 2010; 21(4): 860-863, doi: 10.1093/annonc/mdp508, indexed in Pubmed: 19887465.

63. Damaj G, Gressin R, Bouabdallah K, et al. Results from a prospective, open-label, phase II trial of bendamustine in refractory or relapsed T-cell lymphomas: the BENTLY trial. J Clin Oncol. 2013; 31(1): 104-110, doi: 10.1200/JCO.2012.43.7285, indexed in Pubmed: 23109692.

64. Zhang XM, Li YX, Wang WH, et al. Survival advantage with the addition of radiation therapy to chemotherapy in early stage peripheral T-cell lymphoma, not otherwise specified. Int J Radiat Oncol Biol Phys. 2013; 85(4): 1051-1056, doi: 10.1016/j. ijrobp.2012.08.015, indexed in Pubmed: 23021436.

65. Zhang XM, Li YX, Wang WH, et al. Favorable outcome with doxorubicin-based chemotherapy and radiotherapy for adult patients 
with early stage primary systemic anaplastic large-cell lymphoma. Eur J Haematol. 2013; 90(3): 195-201, doi: 10.1111/ejh.12060, indexed in Pubmed: 23301725.

66. Illidge T, Specht L, Yahalom J, et al. International Lymphoma Radiation Oncology Group. Modern radiation therapy for nodal non-Hodgkin lymphoma-target definition and dose guidelines from the International Lymphoma Radiation Oncology Group. Int J Radiat Oncol Biol Phys. 2014; 89(1): 49-58, doi: 10.1016/j. ijrobp.2014.01.006, indexed in Pubmed: 24725689.

67. McMillan A, Ardeshna KM, Cwynarski K, et al. British Committee for Standards in Haematology. Guideline on the prevention of secondary central nervous system lymphoma: British Committee for Standards in Haematology. Br J Haematol. 2013; 163(2): 168-181, doi: 10.1111/bjh.12509, indexed in Pubmed: 24033102.

68. Forero-Torres A, Leonard JP, Younes A, et al. A phase II study of SGN-30 (anti-CD30 mAb) in Hodgkin lymphoma or systemic anaplastic large cell lymphoma. Br J Haematol. 2009; 146(2): 171-179, doi: 10.1111/j.1365-2141.2009.07740.x, indexed in Pubmed: 19466965 .

69. Smith SM, Burns LJ, van Besien K, et al. Hematopoietic cell transplantation for systemic mature T-cell non-Hodgkin lymphoma. J Clin Oncol. 2013; 31(25): 3100-3109, doi: 10.1200/ /JCO.2012.46.0188, indexed in Pubmed: 23897963.

70. Gisselbrecht C, Glass B, Mounier N, et al. Salvage regimens with autologous transplantation for relapsed large B-cell lymphoma in the rituximab era. J Clin Oncol. 2010; 28(27): 4184-4190, doi: 10.1200/JCO.2010.28.1618, indexed in Pubmed: 20660832.

71. Armitage JO. The evolving role of autologous hematopoietic stem cell transplantation for the treatment of patients with lymphoma. Curr Hematol Rep. 2003; 2(5): 363-365, indexed in Pubmed: 12932307.

72. Biswas T, Dhakal S, Chen R, et al. Involved field radiation after autologous stem cell transplant for diffuse large B-cell lymphoma in the rituximab era. Int J Radiat Oncol Biol Phys. 2010; 77(1): 79-85, doi: 10.1016/j.ijrobp.2009.04.036, indexed in Pubmed: 19647953.

73. Lowry L, Smith P, Qian W, et al. Reduced dose radiotherapy for local control in non-Hodgkin lymphoma: a randomised phase III trial. Radiother Oncol. 2011; 100(1): 86-92, doi: 10.1016/j. radonc.2011.05.013, indexed in Pubmed: 21664710.

74. Spaepen K, Stroobants S, Dupont P, et al. Prognostic value of pretransplantation positron emission tomography using fluorine 18-fluorodeoxyglucose in patients with aggressive lymphoma treated with high-dose chemotherapy and stem cell transplantation. Blood. 2003; 102(1): 53-59, doi: 10.1182/blood-2002-12-3842, indexed in Pubmed: 12609836.

75. Derenzini E, Musuraca G, Fanti S, et al. Pretransplantation positron emission tomography scan is the main predictor of autologous stem cell transplantation outcome in aggressive B-cell non-Hodgkin lymphoma. Cancer. 2008; 113(9): 2496-2503, doi: 10.1002/cncr.23861, indexed in Pubmed: 18833583.

76. Hoppe BS, Moskowitz CH, Zhang Z, et al. The role of FDG-PET imaging and involved field radiotherapy in relapsed or refractory diffuse large B-cell lymphoma. Bone Marrow Transplant. 2009; 43(12): 941-948, doi: 10.1038/bmt.2008.408, indexed in Pubmed: 19139730.

77. Johnston PB, Wiseman GA, Micallef INM. Positron emission tomography using F-18 fluorodeoxyglucose pre- and post-autologous stem cell transplant in non-Hodgkin's lymphoma. Bone Marrow Transplant. 2008; 41(11): 919-925, doi: 10.1038/bmt.2008.82, indexed in Pubmed: 18391991.
78. Sauter CS, Matasar MJ, Meikle J, et al. Prognostic value of FDG-PET prior to autologous stem cell transplantation for relapsed and refractory diffuse large B-cell lymphoma. Blood. 2015; 125(16): 2579-2581, doi: 10.1182/blood-2014-10-606939, indexed in Pubmed: 25758829.

79. Friedberg JW, Neuberg D, Monson E, et al. The impact of external beam radiation therapy prior to autologous bone marrow transplantation in patients with non-Hodgkin's lymphoma. Biol Blood Marrow Transplant. 2001; 7(8): 446-453, doi: 10.1016/s1083-8791(01)80012-4, indexed in Pubmed: 11569890.

80. Wendland MMM, Smith DC, Boucher KM, et al. The impact of involved field radiation therapy in the treatment of relapsed or refractory non-Hodgkin lymphoma with high-dose chemotherapy followed by hematopoietic progenitor cell transplant. Am J Clin Oncol. 2007; 30(2): 156-162, doi: 10.1097/01.coc. 0000251242.32763.35, indexed in Pubmed: 17414465.

81. Ardeshna KM, Kakouros N, Qian W, et al. Conventional second-line salvage chemotherapy regimens are not warranted in patients with malignant lymphomas who have progressive disease after first-line salvage therapy regimens. Br J Haematol. 2005; 130(3): 363-372, doi: 10.1111/j.1365-2141.2005.05603.x, indexed in Pubmed: 16042685.

82. Elstrom RL, Martin P, Ostrow K, et al. Response to second-line therapy defines the potential for cure in patients with recurrent diffuse large B-cell lymphoma: implications for the development of novel therapeutic strategies. Clin Lymphoma Myeloma Leuk. 2010; 10(3): 192-196, doi: 10.3816/CLML.2010.n.030, indexed in Pubmed: 20511164.

83. Vose JM, Anderson JR, Kessinger A, et al. High-dose chemotherapy and autologous hematopoietic stem-cell transplantation for aggressive non-Hodgkin's lymphoma. J Clin Oncol. 1993; 11(10): 1846-1851, doi: 10.1200/JCO.1993.11.10.1846, indexed in Pubmed: 8105034.

84. Rezvani AR, Storer B, Maris M, et al. Nonmyeloablative allogeneic hematopoietic cell transplantation in relapsed, refractory, and transformed indolent non-Hodgkin's lymphoma. J Clin Oncol. 2008; 26(2): 211-217, doi: 10.1200/JCO.2007.11.5477, indexed in Pubmed: 18056679.

85. Thomson KJ, Morris EC, Bloor A, et al. Favorable long-term survival after reduced-intensity allogeneic transplantation for multiple-relapse aggressive non-Hodgkin's lymphoma. J Clin Oncol. 2009; 27(3): 426-432, doi: 10.1200/JCO.2008.17.3328, indexed in Pubmed: 19064981.

86. Sirvent A, Dhedin N, Michallet M, et al. Low nonrelapse mortality and prolonged long-term survival after reduced-intensity allogeneic stem cell transplantation for relapsed or refractory diffuse large B cell lymphoma: report of the Société Française de Greffe de Moelle et de Thérapie Cellulaire. Biol Blood Marrow Transplant. 2010; 16(1): 78-85, doi: 10.1016/j.bbmt.2009.09.002, indexed in Pubmed: 19744569.

87. van Kampen RJ, et al. Allogeneic stem-cell transplantation as salvage therapy for patients with diffuse large B-cell non-Hodgkin's lymphoma relapsing after an autologous stem-cell transplantation: an analysis of the European Group for Blood and Marrow Transplantation Registry. J Clin Oncol. 2011; 29(10): 1342-1348, doi: 10.3410/f.9783970.10482070.

88. Bacher U, Klyuchnikov E, Le-Rademacher J, et al. Lymphoma Working Committee of the CIBMTR. Conditioning regimens for allotransplants for diffuse large B-cell lymphoma: myeloablative or reduced intensity? Blood. 2012; 120(20): 4256-4262, doi: 10.1182/ /blood-2012-06-436725, indexed in Pubmed: 23007405.

89. Freytes C, Zhang MJ, Carreras J, et al. Outcome of lower-intensity allogeneic transplantation in non-Hodgkin lymphoma after 
autologous transplantation failure. Biol Blood Marrow Transplant. 2012; 18(8): 1255-1264, doi: 10.1016/j.bbmt.2011.12.581.

90. Corradini P, Dodero A, Farina L, et al. Gruppo Italiano Trapianto di Midollo Osseo. Allogeneic stem cell transplantation following reduced-intensity conditioning can induce durable clinical and molecular remissions in relapsed lymphomas: pre-transplant disease status and histotype heavily influence outcome. Leukemia. 2007; 21(11): 2316-2323, doi: 10.1038/sj.leu.2404822, indexed in Pubmed: 17597807.

91. Corradini P, Dodero A, Zallio F, et al. Graft-versus-lymphoma effect in relapsed peripheral T-cell non-Hodgkin's lymphomas after reduced-intensity conditioning followed by allogeneic transplantation of hematopoietic cells. J Clin Oncol. 2004; 22(11): 2172-2176, doi: 10.1200/JCO.2004.12.050, indexed in Pubmed: 15169805.

92. Dodero A, Spina F, Narni F, et al. Allogeneic transplantation following a reduced-intensity conditioning regimen in relapsed/ /refractory peripheral T-cell lymphomas: long-term remissions and response to donor lymphocyte infusions support the role of a graft-versus-lymphoma effect. Leukemia. 2012; 26(3): 520-526, doi: 10.1038/leu.2011.240, indexed in Pubmed: 21904377.

93. Kim SW, Tanimoto TE, Hirabayashi N, et al. Myeloablative allogeneic hematopoietic stem cell transplantation for non-Hodgkin lymphoma: a nationwide survey in Japan. Blood. 2006; 108(1): 382-389, doi: 10.1182/blood-2005-02-0596, indexed in Pubmed: 16522821.

94. Rodriguez R, Nademanee A, Ruel N, et al. Comparison of reduced-intensity and conventional myeloablative regimens for allogeneic transplantation in non-Hodgkin's lymphoma. Biol Blood Marrow Transplant. 2006; 12(12): 1326-1334, doi: 10.1016/j. bbmt.2006.08.035, indexed in Pubmed: 17162215.

95. Hamadani M, Saber W, Ahn KW, et al. Impact of pretransplantation conditioning regimens on outcomes of allogeneic transplantation for chemotherapy-unresponsive diffuse large B cell lymphoma and grade III follicular lymphoma. Biol Blood Marrow Transplant. 2013; 19(5): 746-753, doi: 10.1016/j.bbmt.2013.01.024, indexed in Pubmed: 23380340.

96. Sallah S, Wan JY, Nguyen NP. Treatment of refractory T-cell malignancies using gemcitabine. Br J Haematol. 2001; 113(1): 185-187, doi: 10.1046/j.1365-2141.2001.02743.x, indexed in Pubmed: 11328299 .

97. Dueck G, Chua N, Prasad A, et al. Interim report of a phase 2 clinical trial of lenalidomide for T-cell non-Hodgkin lymphoma. Cancer. 2010; 116(19): 4541-4548, doi: 10.1002/cncr.25377, indexed in Pubmed: 20572046.

98. O'Connor OA, Horwitz S, Masszi T, et al. Belinostat in patients with relapsed or refractory peripheral T-cell lymphoma: results of the pivotal phase II BELIEF (CLN-19) study. J Clin Oncol. 2015; 33(23): 2492-2499, doi: 10.1200/JCO.2014.59.2782, indexed in Pubmed: 26101246.

99. Zhou Z, Li X, Chen C, et al. Effectiveness of gemcitabine, pegaspargase, cisplatin, and dexamethasone (DDGP) combination chemotherapy in the treatment of relapsed/refractory extranodal NK/T cell lymphoma: a retrospective study of 17 patients. Ann Hematol. 2014; 93(11): 1889-1894, doi: 10.1007/s00277-014-2136-7.

100. Mahadevan D, Unger JM, Spier CM, et al. Phase 2 trial of combined cisplatin, etoposide, gemcitabine, and methylprednisolone (PEGS) in peripheral T-cell non-Hodgkin lymphoma: Southwest Oncology Group Study S0350. Cancer. 2013; 119(2): 371-379, doi: 10.1002/cncr.27733, indexed in Pubmed: 22833464.

101. Gambacorti-Passerini C, Messa C, Pogliani EM. Crizotinib in anaplastic large-cell lymphoma. N Engl J Med. 2011; 364(8): 775-776, doi: 10.1056/NEJMc1013224, indexed in Pubmed: 21345110.
102. Mossé YP, Lim MS, Voss SD, et al. Safety and activity of crizotinib for paediatric patients with refractory solid tumours or anaplastic large-cell lymphoma: a Children's Oncology Group phase 1 consortium study. Lancet Oncol. 2013; 14(6): 472-480, doi: 10.1016/ /S1470-2045(13)70095-0, indexed in Pubmed: 23598171.

103. Friedberg JW, Mahadevan D, Cebula E, et al. Phase II study of alisertib, a selective Aurora A kinase inhibitor, in relapsed and refractory aggressive B- and T-cell non-Hodgkin lymphomas. J Clin Oncol. 2014; 32(1): 44-50, doi: 10.1200/JCO.2012.46.8793, indexed in Pubmed: 24043741.

104. Sonnen R, Schmidt WP, Müller-Hermelink HK, et al. The International Prognostic Index determines the outcome of patients with nodal mature T-cell lymphomas. Br J Haematol. 2005; 129(3): 366-372, doi: 10.1111/j.1365-2141.2005.05478.x, indexed in Pubmed: 15842660.

105. Tsukasaki K, Utsunomiya A, Fukuda H, et al. Japan Clinical Oncology Group Study JCOG9801. VCAP-AMP-VECP compared with biweekly CHOP for adult T-cell leukemia-lymphoma: Japan Clinical Oncology Group Study JCOG9801. J Clin Oncol. 2007; 25(34): 5458-5464, doi: 10.1200/JC0.2007.11.9958, indexed in Pubmed: 17968021.

106. Huang MJ, Jiang Yu, Liu WP, et al. Early or up-front radiotherapy improved survival of localized extranodal NK/T-cell lymphoma, nasal-type in the upper aerodigestive tract. Int J Radiat Oncol Biol Phys. 2008; 70(1): 166-174, doi: 10.1016/j.jirobp.2007.05.073, indexed in Pubmed: 17919841.

107. Bi XW, Li YX, Fang H, et al. High-dose and extended-field intensity modulated radiation therapy for early-stage NK/T-cell lymphoma of Waldeyer's ring: dosimetric analysis and clinical outcome. Int J Radiat Oncol Biol Phys. 2013; 87(5): 1086-1093, doi: 10.1016/j.jirobp.2013.08.040, indexed in Pubmed: 24120822.

108. Yamaguchi M, Tobinai K, Oguchi M, et al. Phase I/II study of concurrent chemoradiotherapy for localized nasal natural killer/T-cell lymphoma: Japan Clinical Oncology Group Study JCOG0211. J Clin Oncol. 2009; 27(33): 5594-5600, doi: 10.1200/ /JCO.2009.23.8295, indexed in Pubmed: 19805668.

109. Kim SJ, Kim K, Kim BS, et al. Phase II trial of concurrent radiation and weekly cisplatin followed by VIPD chemotherapy in newly diagnosed, stage IE to IIE, nasal, extranodal NK/T-cell lymphoma: Consortium for Improving Survival of Lymphoma study. J Clin Oncol. 2009; 27(35): 6027-6032, doi: 10.1200/JCO.2009.23.8592, indexed in Pubmed: 19884539.

110. Tse E, Kwong YL. Management of advanced NK/T-cell lymphoma. Curr Hematol Malig Rep. 2014; 9(3): 233-242, doi: 10.1007/ /s11899-014-0216-3, indexed in Pubmed: 24924658.

111. Jaccard A, Petit B, Girault S, et al. L-asparaginase-based treatment of 15 western patients with extranodal NK/T-cell lymphoma and leukemia and a review of the literature. Ann Oncol. 2009; 20(1): 110-116, doi: 10.1093/annonc/mdn542, indexed in Pubmed: 18701429 .

112. Kwong YL, Kim WS, Lim ST, et al. SMILE for natural killer/T-cell lymphoma: analysis of safety and efficacy from the Asia Lymphoma Study Group. Blood. 2012; 120(15): 2973-2980, doi: 10.1182/ /blood-2012-05-431460, indexed in Pubmed: 22919026.

113. Jaccard A, Gachard N, Marin B, et al. GELA and GOELAMS Intergroup. Efficacy of L-asparaginase with methotrexate and dexamethasone (AspaMetDex regimen) in patients with refractory or relapsing extranodal NK/T-cell lymphoma, a phase 2 study. Blood. 2011; 117(6): 1834-1839, doi: 10.1182/blood-2010-09-307454, indexed in Pubmed: 21123825. 
114. Kim WS, Song SY, Ahn YC, et al. CHOP followed by involved field radiation: is it optimal for localized nasal natural killer/T-cell lymphoma? Ann Oncol. 2001; 12(3): 349-352, doi: 10.1023/a:1011144911781, indexed in Pubmed: 11332147.

115. Yang Li, Liu $\mathrm{H}, \mathrm{Xu} \mathrm{Xh}$, et al. Retrospective study of modified SMILE chemotherapy for advanced-stage, relapsed, or refractory extranodal natural killer (NK)/T cell lymphoma, nasal type. Med Oncol. 2013; 30(4): 720, doi: 10.1007/s12032-013-0720-7, indexed in Pubmed: 24062259.

116. Yamaguchi M, Tobinai K, Oguchi M, et al. Concurrent chemoradiotherapy for localized nasal natural killer/T-cell lymphoma: an updated analysis of the Japan clinical oncology group study JCOG0211. J Clin Oncol. 2012; 30(32): 4044-4046, doi: 10.1200/ /JC0.2012.45.6541, indexed in Pubmed: 23045573.

117. Sieniawski M, Angamuthu N, Boyd K, et al. Evaluation of enteropathy-associated T-cell lymphoma comparing standard therapies with a novel regimen including autologous stem cell transplantation. Blood. 2010; 115(18): 3664-3670, doi: 10.1182/ /blood-2009-07-231324.

118. Jantunen E, Boumendil A, Finel H, et al. Lymphoma Working Party of the EBMT. Autologous stem cell transplantation for enteropathy-associated T-cell lymphoma: a retrospective study by the EBMT. Blood. 2013; 121(13): 2529-2532, doi: 10.1182/ /blood-2012-11-466839, indexed in Pubmed: 23361910.

119. Ferreri AJM, Govi S, Pileri SA. Hepatosplenic gamma-delta T-cell lymphoma. Crit Rev Oncol Hematol. 2012; 83(2): 283-292, doi: 10.1016/j.critrevonc.2011.10.001, indexed in Pubmed: 22047938.

120. Falchook GS, Vega F, Dang NH, et al. Hepatosplenic gamma-delta T-cell lymphoma: clinicopathological features and treatment. Ann Oncol. 2009; 20(6): 1080-1085, doi: 10.1093/annonc/mdn751, indexed in Pubmed: 19237479.

121. Tanase A, Schmitz N, Stein H, et al. Lymphoma Working Party of the EBMT. Allogeneic and autologous stem cell transplantation for hepatosplenic T-cell lymphoma: a retrospective study of the EBMT Lymphoma Working Party. Leukemia. 2015; 29(3): 686-688, doi: 10.1038/leu.2014.280, indexed in Pubmed: 25234166.

122. Voss MH, Lunning MA, Maragulia JC, et al. Intensive induction chemotherapy followed by early high-dose therapy and hematopoietic stem cell transplantation results in improved outcome for patients with hepatosplenic T-cell lymphoma: a single institution experience. Clin Lymphoma Myeloma Leuk. 2013; 13(1): 8-14, doi: 10.1016/j.clml.2012.09.002, indexed in Pubmed: 23107915.

123. Mourad N, Mounier N, Brière J, et al. Groupe d'Etude des Lymphomes de l'Adulte. Clinical, biologic, and pathologic features in 157 patients with angioimmunoblastic T-cell lymphoma treated within the Groupe d'Etude des Lymphomes de l'Adulte (GELA) trials. Blood. 2008; 111(9): 4463-4470, doi: 10.1182/ /blood-2007-08-105759, indexed in Pubmed: 18292286.

124. Kyriakou C, Canals C, Goldstone A, et al. Outcome-Lymphoma Working Party of the European Group for Blood and Marrow Transplantation. High-dose therapy and autologous stem-cell transplantation in angioimmunoblastic lymphoma: complete remission at transplantation is the major determinant of OutcomeLymphoma Working Party of the European Group for Blood and
Marrow Transplantation. J Clin Oncol. 2008; 26(2): 218-224, doi: 10.1200/JCO.2008.12.6219, indexed in Pubmed: 18182664.

125. Le Gouill S, Milpied N, Buzyn A, et al. Société Française de Greffe de Moëlle et de Thérapie Cellulaire. Graft-versus-lymphoma effect for aggressive T-cell lymphomas in adults: a study by the Société Francaise de Greffe de Moëlle et de Thérapie Cellulaire. J Clin Oncol. 2008; 26(14): 2264-2271, doi: 10.1200/ /JCO.2007.14.1366, indexed in Pubmed: 18390969.

126. Dang NH, Pro B, Hagemeister FB, et al. Phase II trial of denileukin diftitox for relapsed/refractory T-cell non-Hodgkin lymphoma. Br J Haematol. 2007; 136(3): 439-447, doi: 10.1111/j.1365-2141.2006.06457.x, indexed in Pubmed: 17233846.

127. Dearden C. The role of alemtuzumab in the management of T-cell malignancies. Semin Oncol. 2006; 33(2 Suppl 5): S44-S52, doi: 10.1053/j.seminoncol.2006.01.029, indexed in Pubmed: 16720203.

128. Foss FM, Sjak-Shie N, Goy A, et al. A multicenter phase II trial to determine the safety and efficacy of combination therapy with denileukin diftitox and cyclophosphamide, doxorubicin, vincristine and prednisone in untreated peripheral T-cell lymphoma: the CONCEPT study. Leuk Lymphoma. 2013; 54(7): 1373-1379, doi: 10.3109/10428194.2012.742521, indexed in Pubmed: 23278639.

129. Gallamini A, Zaja F, Patti C, et al. Alemtuzumab (Campath-1H) and CHOP chemotherapy as first-line treatment of peripheral T-cell lymphoma: results of a GITIL (Gruppo Italiano Terapie Innovative nei Linfomi) prospective multicenter trial. Blood. 2007; 110(7): 2316-2323, doi: 10.1182/blood-2007-02-074641, indexed in Pubmed: 17581918.

130. Kim JG, Sohn SK, Chae YS, et al. Alemtuzumab plus CHOP as front-line chemotherapy for patients with peripheral T-cell lymphomas: a phase II study. Cancer Chemother Pharmacol. 2007; 60(1): 129-134, doi: 10.1007/s00280-007-0469-9, indexed in Pubmed: 17406867.

131. Zinzani PL, Musuraca G, Tani M, et al. Phase II trial of proteasome inhibitor bortezomib in patients with relapsed or refractory cutaneous T-cell lymphoma. J Clin Oncol. 2007; 25(27): 4293-4297, doi: 10.1200/JCO.2007.11.4207, indexed in Pubmed: 17709797.

132. Delfau-Larue MH, de Leval L, Joly B, et al. Targeting intratumoral B cells with rituximab in addition to CHOP in angioimmunoblastic T-cell lymphoma. A clinicobiological study of the GELA. Haematologica. 2012; 97(10): 1594-1602, doi: 10.3324/ /haematol.2011.061507, indexed in Pubmed: 22371178.

133. Sibon D, Fournier M, Brière J, et al. Long-term outcome of adults with systemic anaplastic large-cell lymphoma treated within the Groupe d'Etude des Lymphomes de l'Adulte trials. J Clin Oncol. 2012; 30(32): 3939-3946, doi: 10.1200/JCO.2012.42.2345, indexed in Pubmed: 23045585.

134. Clemens M, Medeiros L, Butler C, et al. Complete surgical excision is essential for the management of patients with breast implant-associated anaplastic large-cell lymphoma. J Clin Oncol. 2016; 34(2): 160-168, doi: 10.1200/jco.2015.63.3412.

135. Laurent C, Delas A, Gaulard P, et al. Breast implant-associated anaplastic large cell lymphoma: two distinct clinicopathological variants with different outcomes. Ann Oncol. 2016; 27(2): 306-314, doi: 10.1093/annonc/mdv575, indexed in Pubmed: 26598546. 